\title{
AR-GE MERKEZİ DESTEĞİ İLE TURQUALITY PROGRAMININ TASARIM, PATENT VE FAYDALI MODEL TESCIL BAŞVURULARI KAPSAMINDA İHRACAT ÜZERİNDEKI ETKİSINIIN İNCELENMESİ
}

\author{
INVESTIGATION OF THE EFFECT OF TURQUALITY PROGRAM \\ AND R\&D CENTER ON EXPORT IN THE SCOPE OF DESIGN, \\ PATENT AND UTILITY MODEL REGISTRATION APPLICATIONS
}

\author{
Murat ONUR ${ }^{*}$
}

Öz

Ülkeler istihdam, ihracat ve kalkınma gibi pek çok temel ekonomik hedefleri gerçekleştirmek için günümüzde belirli ölçülerde standartlaşmış teşvikler uygulamaktadırlar. Teşvikler, söz konusu temel hedefleri gerçekleştirmenin yanı sıra Ar-Ge kapasitesinin artırılarak katma değeri yüksek teknolojilerin geliştirilmesi, işletmelerin rekabet güçlerinin arttırılması gibi belirli alanlarda da kullanılan bir politika aracı haline gelmiştir. Teşvikler, bu önemi dolayısıyla ekonomi yönetiminin kullandığı temel araçlarından birisidir. İster Ar-Ge ister kalkınma olsun teşviklerin temelinde, uzun vadede kısıtlı olan kaynakların ülke ekonomisine yönlendirilmesiyle halkın refah seviyesinin arttırılması vardır. Bu çalışmada, kamu kaynaklarının etkin kullanılmasını sağlamak amacıyla, Türkiye’de imalat sanayinin alt sektörlerinde gerçekleşen patent, faydalı model ve tasarım tescil başvuru verileri kapsamında Ar-Ge desteği olan Ar-Ge merkezleri desteği ile ihracat desteği olan TURQUALITY programının ihracat üzerindeki etkisi karşılaştırmalı olarak incelenmiştir.

Anahtar Kelimeler: Teşvik, Tescil Başvuruları, İhracat, Ar-Ge, TURQUALITY

JEL Sınıflandırması: E62, E22, O23

\section{Abstract}

Countries are currently applying standardized incentives to a certain extent to achieve many basic economic objectives, such as employment, exports and development. In addition to achieving basics aid objectives, incentives have become a policy tool used in more specific areas such as development of high value-added Technologies by increasing the R\&D capacity and increasing the competitiveness of enterprises. Incentives are therefore one of the basic tools of economy management. The incentives, whether R\&D or development, are based on increasing the welfare of the population by directing scarce resources for the benefit of the national economy. In this study, in order to ensure the efficient

* Türk Patent ve Marka Kurumu, E-posta: murat.onur@turkpatent.gov.tr, Orcid: 0000-0002-8462-1853 
use of public resources, impact of R\&D supports which is $R \& D$ centers and export support which is TURQUALITY program on the export were investigated comparatively within the scope of patent, utility model and design registration applications that occur in sub-sectors of the manufacturing industry in Turkey

Keywords: Incentive, Registration Applications, Export, R\&D, TURQUALITY

JEL Classification: E62, E22, O23.

\section{Giriş}

Türkiye, ekonomik gelişmişlik seviyesine göre hemen hemen her alanda, en çok teşvik programı uygulayan ülkelerden biri olmasına rağmen, bu uygulamaların kayda değer bir çlktıya dönüşmediği görülmektedir. Türkiyede verimliliği esas almadan uygulanan teşviklerden elde edilen kazanımlar şeffaf ve ölçülebilir olmamakta ve bunun doğal bir sonucu olarak teşviklerin etkinliği tam olarak ortaya konamamaktadır (Takım ve Ersungur, 2018). Türkiye'de, pek çok alanda teşvik programı uygulanmasına rağmen bu programların büyük bir bölümü ihracata ilişkin teşviklerinden oluşmaktadır. Ancak, Türkiye’de ihracatın artırılmasına yönelik uygulanan birçok teşvike rağmen ihracatta ciddi bir artış kaydedilememiş, dünya çapında tanınırlı̆̆ı olan markalar oluşturulamamıștır.

Doğu Asyảnın ihracata dayalı büyüme modeliyle elde ettiği ekonomik kazanımlar sonrasında gelişmekte olan ülkelerde ihracat ekonomik büyümenin motoru olarak görülmeye başlanmıştır. 1980'den sonra ihracata dayalı büyümeyi kendisine hedef edinen Türk ekonomisinde de ihracatı artıracak pek çok teşvik programı uygulanmaya başlanmıştır.

Türkiyede imalat sanayinin alt sektörlerinde faaliyet gösteren Ar-Ge merkezlerinin ve bu sektörlerin TURQUALITY programından faydalanma durumlarının bu sektörlerin ihracat performansları üzerinde bir etkisi bulunmaktadır. Ancak, Türkiyede imalat sanayinin alt sektörlerinde uygulanan söz konusu destek programlarının imalat sanayinin alt sektörlerinde nasıl bir etkiye sahip olduğuna ilişkin bir etki analizinin yapılmaması kamu kaynaklarının etkin kullanılması açısından önemli bir sorun oluşturmaktadır.

Bu çalışmada söz konusu eksiklikler göz önünde bulundurularak, Türkiye’de imalat sanayinin alt sektörlerinde gerçekleşen patent, faydalı model ve tasarım tescil başvuru verileri kapsamında Ar-Ge desteği olan Ar-Ge merkezleri desteğinin ve ihracat desteği olan TURQUALITY programının ihracat üzerindeki etkisinin karşılaştırmalı olarak ortaya konması amaçlanmıştır.

\section{Literatür}

İktisadi düşüncenin geçmişten günümüze gelişimine bakıldığında, devletlerin yönetim şekillerinde ve yönetim anlayışlarında çok farklı fikirlerin ve politikaların uygulandığ görülmektedir. Devletin piyasaya müdahalesine ilişkin ortaya konan ilk fikirler, feodal yapının sona ermesi neticesinde piyasa ekonomisine geçiş ile paranın ekonomide kullanılmasıyla 
birlikte ve kapitalizmin yükselmeye başladığı 1500 'lerden 1800 'lere kadar olan "Merkantilizm" döneminde ortaya konmuştur (Sarı̈z, 2006).Merkantilist düşüncede üretimin ve ihracatın artırılarak sanayinin gelişiminin sağlanması, çalışan ücretlerinin belirlenmesi vb. pek çok konuda devletin ekonomiye müdahalesinin gerekli olduğu düşüncesi yaygin bir şekilde hâkimdir.

17. yüzyılın ikinci döneminde Fransa'da "fizyokratlar" olarak anılan yeni bir akım Merkantilizme karşı ortaya çımış ve devletin ekonomiye müdahalesine sert bir şekilde karşı durmuştur (Çaklı, 1998). Fizyokratik düşünceye dayanan "Klasik Liberalizm" de düzenin ekonominin işleyişi ile birlikte kendi kendine oluşacağı düşüncesiyle devlet müdahalesine karşı çıkmıştır. Ayrıca, klasik liberalizm öncüleri, ekonomide Adam Smith'in "görünmez el" anlayışının hâkim olduğunu, bireylerin kendi çıkarlarını artırmak istemeleri durumunda toplumun faydasının da artacağını söylemiş ve bu sebeple devletin ekonomiye müdahalelisine karşı durmuşlardır.

20. yy.ın başlaması ile birlikte bütün dünyada sermayeye ulaşma, işsizlik, enflasyon vb. ekonomik problemler ortaya çıkmaya başlamıştır. Bununla birlikte, 1929'da bütün dünyayı saran "Ekonomik Buhran" neticesinde devletin piyasaya müdahalesine sürekli karşı çıkan klasik düşünce akımına karşı çok ciddi itirazlar yükselmeye başlamıştır. Bu dönemde Keynes, 1936 yılında yayınladığ1 "Faiz, İstihdam ve Paranın Genel Teorisi" isimli kitabında anlattığı yeni bir iktisadi düşünce modeli ortaya koymuştur (Duran, 1998). Buna göre Keynes, ekonominin kendi kendine tam istihdam dengesine ulaşmasının genel değil özel bir sonuç olduğunu savunmuş ve ekonomilerin tam istihdam dengesine ulaşmasını sağlamak amacıyla sadece para politikasının değil aynı zamanda maliye politikasının da kullanılması ve uygulanması gerektiğini ifade etmiştir (Kazgan, 1978).

Ekonomi yönetim anlayışında yaşanan bu gelişmeler sonucunda devletin ekonomi ile olan ilişsisinde ciddi değişimler yaşanmıştır. Artık, devlet sadece "bekçi-jandarma" görevi üstlenmemekte ve piyasada üretim ve tüketim üzerinde doğrudan etkili olan bir yapı olarak görev yapmaya başlamıştır (Eser, 2011). Devletler, düzenleme ve denetleme amacıyla hem toplumsal refahı arttırmak amacıyla hem de belirli alanlarda yatırımlara öncülük etmek amacıyla ekonomiye eskisinden daha çok müdahale etmeye başlamıştır (Eser, 2011).Diğer bir ifadeyle, ekonomik ve sosyal hayatın merkezinde yer alan devlet ekonomiye hem doğrudan hem de dolaylı olarak her zaman müdahale etmektedir (Tosun, 1996). Bu itibarla, gelişmişlik seviyesi ne olursa olsun bütün devletlerin yaşanan ekonomik ve sosyal problemleri çözmek amacıyla uyguladığ1 teşvikler kamunun piyasaya müdahale ederken başvurduğu en önemli araçlardan birisi haline gelmiştir.

\section{I. Teşvik Kavramı}

TDK'ya göre teşvik kavramı, özendirme ve isteklendirme şeklinde açıllanmakta ve bir ekonomik amacı gerçekleştirmek için uygulanan maddi yardım ve idari kolaylıklar biçiminde verilen destekler şeklinde tanımlanmaktadır. DPT'ye göre ise teşvik, gelişmesi istenen üretim sektörlerinin 
veya faaliyetlerin gelişmesini hızlandırmak amacıyla, devlet tarafından farklı yöntemlerle verilen maddi veya gayri maddi yardım, destek ve özendirmeler şeklinde tanımlanmaktadır (DPT, 2007).

Teşvik kavramı pek çok farklı açıdan açıklanmaktadır. Ancak, genel anlamda teşvik, ülkelerin gelişmişlik düzeylerine göre belirledikleri kalkınma stratejilerini gerçekleştirmek amacıyla stratejik aktivitelerin yapılmasını özendirmek için kamu tarafından verilen maddi ve maddi olmayan yardımlar olarak tanımlanabilir (ATO, 2000).

Diğer bir ifadeyle teşvik, daha hızlı gelişmesi istenen faaliyetlerin yapılmasını sağlamak amacıyla, devlet tarafından farklı yöntemlerle verilen maddi ve maddi olmayan yardımlar ve özendirmeler olarak tanımlanabilir (Çiloğlu, 1997).

Kullanım amacına göre teşvik kavramı farklı şekillerde tanımlanabilir. Hazine Müsteşarlığı Teşvik ve Uygulama Genel Müdürlüğü teşviki "belirli ekonomik faaliyetlerin diğerlerine oranla daha fazla ve hızlı gelişmesini sağlamak amacıyla kamu tarafından çeşitli yöntemlerle verilen maddi ve gayri maddi destek, yardım ve özendirmelerdir” şeklinde tanımlamaktadır.

\subsection{Dünya'da Teşvik Uygulamaları}

Dünya’daki teşvik eğilimlerine baktığımızda, söz konusu teşvik eğilimlerinin 1980 öncesi dönemde yatırımcıları destekleyici politikalar şeklindeyken, 1980'de başlayan liberalleşme hareketiyle küresel yabancı yatırımcıları çekmek üzerine odaklandığı görülmektedir.

Asya ülkelerinin belirli faaliyet ve sektörleri özendirmesi, söz konusu faaliyet ve sektörlere yönelik uzun dönemli uygulanan vergi muafiyetleri, ulusal yerine bölgesel teşvik sistemlerinin uygulanması ve bu ülkelerde ihracatçı firmalara yönelik uluslararası piyasalarda rekabet gücü elde edilmesine yönelik uygulanan teşvikler yatırımlara çok ciddi katkılar sağlamıştır (Karakurt, 2010). Asya ülkelerinde yaşanan bütün bu gelişmeler ile birlikte bu ülkelerin hem gelir dağılımında adaleti sağladıkları hem de yoksulluk ile mücadelede diğger ülkelere kıyasla daha başarılı oldukları kaydedilmiştir (Şenses, 2009).

Güney Kore, kaydettiği ekonomik gelişme açısından bütün ülkelere örnek olmuş ve bu yönüyle pek çok çalışmanın konusu olmuştur. 1960 ve 1970 döneminde Güney Kore'de uygulanan politikalar incelendiğinde, söz konusu politikaların temel niteliğinin ve ortak noktalarının yatırımların büyük bir kısmının devlet eliyle gerçekleştiriliyor olmasıdır. Bu dönemde Güney Kore'de uygulanan teşvik programları, firma performansını esas almış ve başarılı olan firmalara yönelik hazırlanmış özel teşvik programlarının uygulanması üzerine odaklanmıștır. Güney Kore, uyguladığı teşviklere ilişkin benimsediği bu temel felsefe ile başarılı firmaları ödüllendirirken başarısız firmaları ise teşvik sistemi dışında tutmuştur (Ministry of Finance and Economy Republic of Korea sand KDI School of Public Policy and Management, 2006).Güney Kore, uyguladığı politikalar sayesinde ihracatını 1950'li yıllarda yüzde 3,1960'lı yıllarda yüzde 30, 1970'li yıllarda ise yüzde 40 arttırmıştır (Ministry of Finance and Economy Republic of Korea and 
KDI School of Public Policy and Management, 2006).Güney Kore, 1970'li yıllarda benimsediği ihracatı geliştirme stratejisini daha sonraki ylllarda stratejik sektörlerin geliştirilmesi stratejisine dönüştürmüştür.

Güney Kore, 1980 ve 1990 'larda sektörel teşviklerin piyasa aksaklıklarına sebep olmasıve teşviklerin belirli firmalara kullandırılmasının oluşturduğu sorunlar nedeniyle teşvik politikalarında firma bazında sektörel teşvik uygulamalarını terk etmiştir. Bu dönemde Güney Kore, Ar-Ge, KOBİ gibi sektörel olmayan alanlara yönelik teşvikler uygulayarak ekonomi içerisinde yer alan her birimin teşviklerden eşit oranda faydalanmasını amaçlamıştır. Günümüzde ise Güney Kore’de sektörlere yönelik uygulanan özel teşvik programları terk edilmiş bunun yerine katma değeri yüksek olan faaliyetlerin ve bu faaliyetlere yönelik Ar-Ge çalışmalarının desteklenmesi esas alınmıştır.

Dünyanın en büyük ekonomilerinden ve ihracatçılarından biri olan Çin’in uyguladığı teşvik politikaları da oldukça dikkat çekmektedir. Çin, 1980'lerde yabancı yatıımcılara kapılarını açmış ve yüksek teknolojili sektörlerin ve altyapının gelişimi noktasında yabancı yatırımı teşvik eden, ihracatın artırılmasını esas alan bir politika benimsemeye başlamıştır (Lu, 1999). Bu dönemde Çin, izlediği "açık kapı" politikası ile küresel ekonomiye entegre olmaya ve yüksek teknolojili sektörlerin gelişmesine çalışmıştır (Sigurdson, 2003).Çin, yeni teknolojilerin ülkeye girişini destekleyerek yerel Ar-Ge faaliyetlerinin gelişmesini hedeflemiştir (Oshima, 1993).

Çin, 1982'de "Stratejik Bilim ve Teknoloji Programı"nı hazırlamış ve 1986'dan itibaren "İleri teknoloji Ar-Ge Programı”nı uygulamaya başlamıştır. Ayrıca, Çin 1996'da inovasyon kapasitesini arttırarak uluslararası rekabet gücü kazanmak amacıyla "Ulusal Teknik İnovasyon Programı”nı ilan etmiştir (Chine Ministry of Science and Technology, 2007). Çin, 2001'de ise "10. Beş Yıllık Kalkınma Planı” kapsamında ulusal bilim ve teknoloji programını uygulamaya başlamıştır. $\mathrm{Bu}$ programın amacı yüksek teknolojili sektörlerin inovasyon kapasitesini arttırarak söz konusu sektörlerin rekabet gücü kazanmalarını sağlamak olmuştır (Chine Ministry of Science and Technology, 2007).İhracat temelli büyümeyi kendisine hedef edinen Çin Hükümetinin teknoloji kapasitesini artırmaya yönelik yapmış olduğu çok sayıda girişim ve bu yöndeki uyguladığı teşvik sistemi başarılı olmuş ve Çin çok kısa bir sürede, dünyanın üretim ana üssü haline gelmiştir (Yusuf ve Nabeshima, 2007).

İlanda, uyguladığı teşvik politikaları ile kayda değer ekonomik gelişme gösteren ülkelerden bir diğeri olarak karşımıza çıkmaktadır. İrlanda için en önemli gelişmelerin yaşandığı 1950-1960 arası dönemde, korumac1, ithal ikameci ve yabancı sermayenin ülkeye girişini engelleyen politikalar terk edilmiş ve ihracat ile yabancı sermayeyi destekleyen tedbirler alınmıştır (O'Donnell, 1998). İrlanda, bu dönemde uluslararası firmaları ülkeye çekmek için ihracata ilişkin finansal teşvikler uygulamış ve ihracat gelirlerinin belirli bir süreliğine vergiden muaf tutulması şeklinde işletmelerin desteklemesi yoluna gitmiştir (Ruane, 2003).İlandảnın, 1970’li yıllarda yabancı sermayeyi çekmek için uyguladığı teşviklerin en belirgin özelliği sektörlere göre oldukça seçici olmalarıydı. Bu kapsamda teşviklerin amacı, ilaç ve elektronik sektörleri başta olmak üzere yüksek teknoloji sektörlerinde yabancı sermayeyi çekmek olurken geleneksel sektörlerde yatırımları terk 
etmek üzerine odaklanmıştır (Eser, 2011). Bu dönemde firma-odaklı ve proje bazlı uygulanan esnek teşvik sistemi sayesinde yabancı sermayenin İrlandảya gelmesi kolaylaşmıştır (Ruane, 2003).

Ekonomik yapısı Türkiye ile benzerlik gösteren Çek Cumhuriyeti’nin son dönemdeki yabancı sermayeyi çekme hususundaki kayda değer başarısı dikkat çekmektedir.1989 sonrası Çek Cumhuriyeti, keskin bir anlayış değişikliği ile yabancı yatırımları çekmeyi hedefleyen bir ekonomik yapıya ve Avrupa'yı öncelikleyen ihracat stratejisine geçmiştir. Çek Cumhuriyeti ekonomi anlayışında yaşanan bu değişiklik ile planlı ekonomiden serbest ekonomiye geçen en başarılı ülkelerden biri olmuş ve küresel piyasaya hızlıca entegre olmuştur (Eser, 2011). Çek Cumhuriyeti, uyguladığı başarılı teşvik politikaları, sahip olduğu eğitimli işgücü, güçlü ekonomisi ve düşük işçilik maliyetleri ile yabancı sermayeyi çekme hususunda oldukça başarılı olmuştur (Günem, 2007).Bu durumun en önemli nedeni, ağır sanayide ülkenin yeterli üretim kültürüne sahip olması ve yatırım taleplerinin bu alanlara yönelmiş olmasıdır (Eser, 2011).

\subsection{Türkiye'de Teşvik Politikalarının Tarihçesi}

Türkiyede geçmişten günümüze uygulanan teşvikler oldukça karmaşı bir yapıya sahiptir. Karmaşıklı, teşviklerin amaç ve hedeflerinin çok olmasının yanı sıra ilgili mevzuat ve programların zor anlaşılan bir yapıda olmaları ve hızlıca değişmelerinden kaynaklanmaktadır (Küçükoğlu, 2005). Bu nedenle, Türkiye’de uygulanan teşvik sistemini anlamak için Türkiyédeki teşvik politikalarının tarihsel gelişimini anlamak ayrıca önem arz etmektedir. Devlet Planlama Teşkilatı (DPT), Türkiyedeki teşvik politikalarının daha iyi analiz edilebilmesi için teşvik politikalarının tarihsel gelişimini “1950 öncesi dönem”, “1950-1960 arası dönem” ve "1960 sonrası planlı dönem” şeklinde üç dönemde ele almaktadır (DPT, 2000).

1950 öncesi dönemde, yatırımların teşvikine ilişkin ülkemizde uygulanan ilk kanuni düzenleme Osmanlı İmparatorluğu zamanında gerçekleştirilmiş, ancak gerçek anlamda Cumhuriyet döneminde uygulamaya konulabilmiştir. Cumhuriyetin kuruluşundan sonra, ilk olarak sanayinin geliştirilmesi üzerine odaklanılmış ve 1923’teki "Birinci İzmir İktisat Kongre" sinden sonra, 1927’de 15 yıllık dönem için "Teşvik-i Sanayi Kanunu” yürürlüğe girmiştir. 1923-1939 döneminde hibrit bir ekonomi yönetimi anlayışıla devletçi-karma ekonomi düşüncesi iktisadi politikada benimsenmiştir (DPT, 1982). Ancak, bütün dünyada yaşanan 1929 ekonomi buhranı ve II. Dünya Savaşının başlamasıyla birlikte amaçlanan hedeflere bu dönemde ulaşılamamıştır.

1950-1960 arası dönemde hızlıca pek çok kanun yürürlüğe girmiştir. Yine bu dönemde, bir diğer önemli gelişme sanayinin finansal ihtiyaçlarını karşılamak ve sanayiye kredi sağlamak için “Türkiye Sınaî ve Kalkınma Bankası”nın kurulması olmuştur.1950-1960 arası dönemde uygulamaya konan kanun ve düzenlemelere bakıldığında bu dönemin bugünün karma ekonomik sistemin ve teşvik uygulamalarının hazırlayıcısı olduğu görülmektedir (Küçükoğlu, 2005). 
1960 ve sonrası dönemde Devlet Planlama Teşkilatı́nın (DPT) kurulmasıyla birlikte yatırımların desteklenmesi, belirli dönemler halinde uygulanan kalkınma planları ve yıllık programlar kapsamında çıkarılan yasal düzenlemeler ile planlı bir şekilde yürütülmeye başlanmıştır (Yerebakan, 2007).1960 sonrası planlı dönemi ekonomi politikaları perspektifinden 24 Ocak 1980 kararları öncesi ve sonrası dönem olmak üzere iki ayrı bölümde analiz etmek gerekmektedir (DPT, 1989).

24 Ocak 1980 kararları öncesi döneme baktığımızda, bu dönemde ekonomi politikalarının korumacı ve ithal ikameciliği benimseyen bir yapıda olduğunu görmekteyiz. Bu dönemdeki politikalar genel olarak sanayinin dış rekabete karşı korunması, sınırlı ithalat ve yüksek gümrük tarifeleri şeklinde uygulanmıştır. Bu dönemde uygulanmaya konan en önemli gelişmeler, yatırım indirimi sağlayan 1963 yılındaki 202 sayılı Kanun ve 193 sayılı “Gelir Vergisi Kanunu”nun hayata geçirilmesi, 1968 yılında 22 ilin “Kalkınmada Öncelikli Yöre (KÖY)”olarak ilan edilmesiyle KÖY uygulamasına başlanması ve “Teşvik Belgesi” sisteminin kurulması olmuştur (Küçükoğlu, 2005).

1970'li yılların ilk döneminde gelişen dünya ekonomisi ile birlikte Türkiye, ithal ikamesini esas alan sanayi politikasını devam ettirmiştir. Ancak, ödemeler dengesindeki yaşadı̆̆ı problemler, ihracata yönelmedeki yetersizlikten dolayı bu politika ile beklenen büyüme kaydedilememiş, ekonomik istikrar sağlanamamış ve bunun neticesinde de ciddi ekonomik problemler ortaya çıkmıştır. Ekonomide yaşanana bu problemler neticesinde 24.01.1980 tarihinde alınan ekonomik istikrar kararlarıyla birlikte Türkiye, ekonomi politikalarında önemli değişikliklere gitmiş ve ekonomik yapısını değiştirmeye başlamıştır.

24 Ocak 1980 kararları sonrasında ekonomide ciddi yapısal değişiklikler yaşanmıştır. İthalat mevzuatında köklü değişikliklere gidilerek "ithal ikamesine dayalı sanayileşme stratejisi” terk edilmiş yerine "ihracata dönük sanayileşme stratejisi” benimsenmiştir (DPT, 2003). Bu kapsamda, teşvik programlarında öncelikli sektör uygulamasına geçilmiş ve bu doğrultuda yapılan yasal düzenlemelerle teşvik edilecek yatırım konuları saptanmıştır.

$\mathrm{Bu}$ dönemde teşviklerle ilgili yaşanan en önemli gelişme 85/10011 sayılı karar ile "Kaynak Kullanımını Destekleme Priminin (KKDP)" uygulamaya konmuş olmasıdır. Bu düzenleme ile birlikte teşviklerin etkisi büyük ölçüde artmış ve bazı sektörlerde yatırımların büyük ölçüde artması sağlanmıştır. Yatırımın yaklaşık yüzde 50'sini karşılayan KKDP uygulaması OSB’lerde, KÖY’lerde, sağlık, eğitim, turizm gibi stratejik sektörlerde yatırımların kayda değer bir şekilde artmasını sağlamıştır. Ancak, 1990’lardan sonra kamuda ciddi bir kaynak sıkıntısı yaşanmış ve bunun neticesinde 1991 yılında KKDP uygulaması kaldırılmıştır.

1990’ların ikinci yarısının başlamasıyla birlikte 94/6411 ve 95/6569 sayılı Kararlar ile sektör bazlı teşvik uygulaması terk edilmiş, Gelişmiş yöreler olarak belirlenen Ankara, Adana, Bursa, İstanbul, İzmir, Kocaeli dışında kalan tüm bölgeler "Sanayi Kuşağı” olarak kabul edilmiş ve sanayi kuşağında yer alan tüm bölgelerin eşit oranda teşviklerden faydalanması sağlanmıştır (Duran, 1998). Ancak "Sanayi Kuşağı" uygulaması da uzun sürmeyerek 98/10755 sayılı karar ile sona erdirilmiş ve yeniden bölgesel teşvik sistemine geçilmiştir. 
1980 öncesinde yatırımları, 1980 sonrasında ise ihracatı desteklemeyi amaçlayan teşvik sistemi 2000'li yıllarda kalkınma, istihdam, Ar-Ge ve KOBİ gibi çeşitli alanlara yönelmiştir. Ancak, teşviklerin bu denli çeşitli alanlarda uygulanması ile birlikte farklı kurumların teşvik sistemine girmesi gerekmiş ve bunun neticesinde daha önce tek elden yönetilen teşvik sistemi değişmiştir. $\mathrm{Bu}$ durum ise hemen hemen her alanda uygulanan teşviklerin maliyetinde artışlara sebep olmuş ve teşviklerden hedeflenen kazancın azalmasına neden olmuştur.

Günümüzde uygulanan teşvik sisteminin karmaşık bir yapıda olduğu, etkin destek araçlarına sahip olmadığı, mükerrerlik oluşturduğu ve performans izleme sistemine sahip olmadığı şeklindeki problemleri Dokuzuncu Kalkınma Planında belirtilmiştir (DPT, 2006).

\subsection{Sınaî Mülkiyet Haklarının Ekonomi Üzerine Etkisi}

Sınaî mülkiyet haklarının ekonomik büyüme üzerine etkileri Dünya Ticaret Örgütünün (DTÖ) 1995 yılında “Ticaretle Bağlantılı Fikri Mülkiyet Hakları Anlaşmasını (TRIPS)” onaylanması ile birlikte daha kuvvetli bir şekilde görünmeye başlanmıştır (Hassan vd., 2010).TRIPS Anlaşması, fikri mülkiyet haklarının uygulanmasına ilişkin DTÖ üyelerinin tabi olduğu ilke ve gereklilikleri belirlemekte ve söz konusu hakların üye ülkelerde ne şekilde uygulanması gerektiğine yönelik usul ve esasları ve çıkabilecek anlaşmazlıkların çözümüne ilişkin hükümleri içermektedir.

Fikri mülkiyet haklarının (FMH) Avrupa ekonomisine gerçek katkısının analiz edilmesi amacıyla hazırlanan 2008-2010 dönemini kapsayan AB Sanayi Analiz Raporu’nda ${ }^{1}$, Avrupa Topluluğunda fikri mülkiyet yoğun sektörlerin istihdama katkısının \%26; Gayri Safi Yurtiçi Hâsılaya katkısının ise \%39 olduğu ifade edilmektedir. Ayrıca, söz konusu raporda, Avrupa Topluluğundan yapılan ihracatın \%90'nının fikri mülkiyet yoğun sektörler tarafından yapıldı̆̆ı vurgulanmıştır (IndustryLevel Analysis Report, 2013).

Sınaî mülkiyet hakları olarak tabir edilen patent, faydalı model ve tasarım tescil başvurularının gayri safi yurtiçi hâsıla (Gould ve Gruben 1996; Park ve Ginarte, 1997), ithalat (Maskus ve Penubarti, 1995), ihracat (Smith, 2001) ve doğrudan yabancı yatırımlar (Maskus ve Konan, 1994) vb. ekonomik göstergeler üzerine etkisini analiz eden birçok çalışma yapılmıştır. Bu çalışmalardan bir bölümü sınaî mülkiyet haklarının ekonomik göstergeler üzerine olumlu etkisinin olduğunu (Maskus ve Penubarti,1995; Gould ve Gruben 1996; Smith, 2001) söylemesine karşın diğer bir bölümü de sınaî mülkiyet hakları ile ekonomik göstergeler arasında istatistikî anlamda kayda değer bir ilişki olmadığını (Maskus ve Konan 1994; Thompson ve Rushing 1996) ifade etmiştir.

Cho vd., (2015), sınaî mülkiyet haklarının ekonomik gelişme üzerine etkisinden çok AR-GE ve inovasyon üzerine etkisinin daha ölçülebilir ve anlamlı olduğunu ancak, bu alandaki sonuçların da farklılık gösterdiğini ifade etmiştir. Mansfield (1986), sınaî mülkiyet haklarının etkinliği konusundaki farklı görüşlerin sebebinin sınaî mülkiyet haklarının birbirine karşı olan AR-GE ve

1 Industry-Level Analysis Report, "IntellectualPropertyRightsIntensiveIndustries: Contribution to economic performance an demployment in the EU”, EPO ve OHIM Ortak Projesi. 2013. 
inovasyon üzerine iki etkisinden kaynaklandığını ifade etmiştir. Patentli bilgi kişiye özel olduğu için sahibine daha fazla fiyat ve pazar avantajı sağlamakta ve bu durum AR-GE ve inovasyonu teşvik etmektedir. Ancak, patentli bilgi aynı zamanda bilginin yayılmasını engelleyerek AR-GE ve inovasyonu olumsuz etkilemektedir (Mansfield, 1986).Bu ikilem doğrultusunda sınaî mülkiyet haklarının etkinliğini inceleyen birçok çalışma sınaî mülkiyet haklarının AR-GE ve inovasyon üzerine etkisinin ülkelere, sektörlere, ülkelerin ekonomik seviyelerine ve sınaî mülkiyet yapılarına göre değişkenlik gösterdiğini ortaya koymuştur (Cohen vd., 1997; Varsakelis, 2001; Lall, 2003; Fink ve Maskus, 2005; Kim vd., 2012).

\subsection{Ar-Ge Merkezleri ve TURQUALITY Programı}

Sanayi ve Teknoloji Bakanlığı, 5746 sayılı "Araştırma, Geliştirme ve Tasarım Faaliyetlerinin Desteklenmesi Hakkında Kanunu” ${ }^{2}$ yayımlamıştır. Söz konusu kanunun amacı, "Ar-Ge ve yenilik yoluyla ülke ekonomisinin uluslararası düzeyde rekabet edebilir bir yapıya kavuşturulması için teknolojik bilgi üretilmesini, üründe ve üretim süreçlerinde yenilik yapılmasını, ürün kalitesi ve standardının yükseltilmesini, verimliliğin artırılmasını, üretim maliyetlerinin düşürülmesini, teknolojik bilginin ticarileşmesini, rekabet öncesi işbirliklerinin gelişmesini, teknoloji yoğun üretim, girişimcilik ve bu alanlara yönelik yatırımlar ile Ar-Ge’ye ve yeniliğe yönelik doğrudan yabancı sermaye yatırımlarının ülkeye girişinin hızlandırılmasını, Ar-Ge personeli ve nitelikli işgücü istihdamının artırılmasını desteklemek ve teşvik etmek” şeklinde belirlenmiştir.

Ar-Ge merkezlerinin kurulmasının temelini oluşturan 5746 Sayılı Kanun ile firmaların Ar-Ge projeleri ${ }^{3}$ ve Ar-Ge faaliyetlerini ${ }^{4}$ yaygınlaştırmaları ve bu doğrultuda ülke ekonomisinin uluslararası seviyede rekabet edebilir bir yapıya kavuşması amaçlanmaktadır.

TURQUALITY, “ülkemizin rekabet avantajını elinde bulundurduğu ve markalaşma potansiyeli olan ürün gruplarına sahip firmalarımızın, üretimlerinden pazarlamalarına, satışlarından satış sonrası hizmetlerine kadar bütün süreçleri kapsayacak şekilde yönetsel bilgi birikimi, kurumsallaşma ve gelişimlerini sağlayarak uluslararası pazarlarda kendi markalarıyla global bir oyuncu olabilmeleri ve söz konusu markalar aracılığıyla olumlu Türk malı imajının oluşturulması ve yerleştirilmesi amacıyla oluşturulmuş devlet destekli bir markalaşma programıdır " ${ }^{\text {”. }}$ TURQUALITY, işletmeleri kurumsal ve operasyonel manada destekleyen bir markalaşma destek programı olarak konumlandırılmaktadır ${ }^{6}$.

2 https://agtm.sanayi.gov.tr/Agm/ArgeDetay

3 Ar-Ge projesi, "Ar-Ge faaliyetlerinin her safhasını belirleyecek mahiyette ve bilimsel esaslar çerçevesinde gerçekleştirilen ve araştırmacı tarafından yürütülen proje” şeklinde tanımlanmıştır. (https://agtm.sanayi.gov.tr/ Agm/ArgeDetay)

4 Ar-Ge faaliyetleri, "Sistematik bir temelde yürütülen yaratıcı çalışmalar, çevre uyumlu ürün tasarımı veya yazılım faaliyetler ile alanında bilimsel ve teknolojik gelişme sağlayan, bilimsel ve teknolojik bir belirsizliğe odaklanan, çıktıları özgün, deneysel, bilimsel ve teknik içerik taşıyan faaliyetler” şeklinde tanımlanmıştır. (https://agtm.sanayi. gov.tr/Agm/ArgeDetay)

5 https://www.turquality.com/hakkimizda

6 https://www.turquality.com/hakkimizda 
TURQUALITY programının hedefleri, "Marka potansiyeli olan firmalara global bir marka olma yolunda finansal kaynak sağlamak, global Türk markaları yaratabilmek için firmaların ve markalarının gelişimlerine yönelik strateji, operasyon, organizasyon ve teknoloji danışmanlığ çalışmaları ile destek olmak, program kapsamında bulunan firmaların yönetim birimlerine yönelik eğitim desteği vermek, yurtdışında olumlu Türk malı imajının oluşturulması ve tutundurulması için iletişim ve tanıtım faaliyetlerinde bulunmak, Türk firmalarının marka bilincini artırmak, Türk firmalarının pazar bilgisi dahilinde aksiyon alabilmeleri için istihbarat desteği sağlamak ve

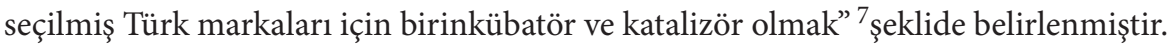

TURQUALTIY destek programının kapsamına ve bu programdan faydalanana firmaların hangi yönlerine katkı sağladığına ilişkin yapılan çalışmaların son dönemde yoğunlaştığı görülmektedir.

Açıkel (2018), Turquality Projesiden faydalanan mobilya sektöründe faaliyet gösteren firmaların küresel pazarlardaki tutundurma faaliyetlerinin incelenmesi konulu çalışmasında söz konusu tutundurma faaliyetlerinin firmaların iletişimlerinin kuvvetlendirilmesi, ürün ve hizmetlerin hedef pazarlara tanıtılması ve ulaştırılması, ürünün öne çıkan avantajlı yönlerinin müşterilere duyurulması ve gerekli bilgilendirmelerin sağlanması vb. bileşenleri kapsadığını ifade etmiştir. Ayrıca, Açıkel (2018) küresel pazarlarda bulunan müşterileri firmanın ürün ve hizmetleri konusunda bilgilendirmek ve onların firmanın ürünlerini satın almalarını sağlamak, yurt içinde olduğu gibi yurt dışında da yine tutundurmanın görevi olduğunu ifade etmiş ve Turquality destek programı ile Türk markalarının küresel pazarlarda etkili bir şekilde konumlandırılmalarının ve tutundurulmalarının amaçlandığını vurgulamıştır.

Tutundurma, firmaların kazanmak istedikleri müşterilerin firmanın ürün ve hizmetlerini talep etmesi için yapılan tanıtım faaliyetleridir (Kotler vd., 2004).

Özbaysal ve Onay (2017),birbirinden farklı üç sektörlerde Turquality Programı kapsamında faaliyet gösteren firmaların markalaşma ve uluslararası bir işletme olma süreçlerini incelemiş ve programa başvuruda bulunup markalaşmak isteyen işletmeler için bir "Yol Haritası" düzenlemiştir. Araştırma sonucunda her üç işletmede de Turquality Programı sonrasında örgüt yapısının kurumsal bir nitelik kazandığı, uluslararası pazarlara girişte daha hızlı hareket kabiliyeti kazanıldığı ve lojistik anlamında büyük avantajlar elde edildiği ifade edilmiş ve işletmelerin organizasyonel anlamdaki sahip oldukları iyileştirmelerin altı çizilmiştir (Özbaysal ve Onay, 2017).

Şener ve Bişğin (2014),Turquality Programından faydalanan Sarar markasını inceledikleri çalışmalarında, Turquality Programının Sarar markasının pazarlama kararları üzerinde ve özellikle tutundurma faaliyetlerine büyük katkısının olduğunu ifade etmiş ve bu kapsamda, tutundurmaya yönelik olan bu destek programının oldukça önemli olduğunun altını çizmiştir. Kızartıcı (2006) ise Turquality Programının Türk tekstil firmalarına kazandırdığı avantajları ortaya koymuştur.

7 https://www.turquality.com/hakkimizda/misyon-ve-hedeflerimiz 
TURQUALITY programının hedefleriyle söz konusu programdan faydalanan işletmeler üzerine yapılan araştırmalarda ulaşılan sonuçlar dikkate alındığında hem programın hedeflerinin hem de firmaların programdan faydalanma şekillerinin işletmelerinin uluslararası pazarlara tutundurulmasını amaçladığı çok açıktır. Dolayısıyla, TURQUALITY programının doğrudan sektörün teknoloji kapasitesini artırmaya yönelik teknoloji esaslı bir destek programı olmadığı, buna karşın programının, sektörde faaliyet gösteren firmalara uluslararası pazarlarda finansal kaynak sağlamak, eğitim, danışmanlık hizmetleri sağlamak ve marka oluşturmak vb. destek kalemlerinde hizmet sunarak işletmelerin ihracat yapabilme kapasitesini artmayı amaçladığı görülmektedir.

\section{Metodoloji, Veriler ve Bulgular}

\section{I. Metodoloji}

Bu çalışmada, Türkiyede uygulanan Ar-Ge merkezleri desteği ve TURQUALITY programı desteğinin, devlet teşviklerinin etkin kullanılması açısından, Türkiye'de imalat sanayinin alt sektörlerinde nasıl yönetilmesi gerektiği ortaya konulmaya çalışılmıştır. Bu çalışmada gerçekleştirilen analizler firma ölçeğinde olmayıp imalat sanayinin alt sektörlerini esas almaktadır. Diğer bir ifadeyle bu çalışmada, imalat sanayinin alt sektörlerinde faaliyet gösteren Ar-Ge merkezlerinin ve bu sektörlerin TURQUALITY programından faydalanma oranlarının ihracat üzerindeki etkileri ortaya konmuştur. Bu doğrultuda, ilk olarak her iki destek sistemine ilişkin elde edilen verilerin ve ihracat verilerinin ayrı ayrı sektörel analizi ve uyumu yapılmışıtır. Ancak, Türkiyede uygulanan Ar-Ge merkezleri ve TURQUALITY programı desteğine ilişkin bir sektörel sınıflandırma yapılmış olmasına karşın söz konusu sınıflandırma işleminde bir sistematik takip edilmemiştir. Ar-Ge merkezlerine ve TURQUALITY programına ilişkin yapılan sektörel sınıflandırma işleminde söz konusu teşviklerden faydalanan firmaların kendi faaliyet alanlarını belirtmeleri şeklinde bir sektörel tasnif işlemi uygulanmıştır.

Bu çalışmada, sınaî mülkiyet hakları olan patent, faydalı model ve tasarım tescil başvuru verilerinin Ar-Ge merkezi desteği ve TURQUALITY programı desteği ile olan ilişkisi analiz edilmiştir. Ayrıca, patent, faydalı model ve tasarım tescil başvuru verilerinin de sektörel analizi ve uyumu yapılmıştır.

Patent, faydalı model ve tasarım tescil başvuru verileri ile Ar-Ge merkezi verilerinin, TURQUALITY programı verilerinin ve ihracat verilerinin sinıflandırılmasında birbirinden tamamen farklı yöntem ve amaca sahip sinıflandırma sistemlerinin kullanılmış olması söz konusu verilerin birbirleriyle analiz edilmesi esnasında karşılaşılan en büyük sorun olurken ilgili sınıflandırma sistemlerinin birbirleriyle uyumunu gerçekleştirmek ise bu çalışmada yapılan ilk iş olmuştur.

Söz konusu verilere ilişkin kullanılan sınıflandırma sistemlerinin hiçbiri endüstri temelli olmadığından, söz konusu sınıflandırma sistemlerinden direkt olarak sektörel istatistiklere 
erişim mümkün olmamakta ve bu verilerden hangisinin esas alınarak bir uyumlaştırma işleminin yapılacağı sorunu da ortaya çıkmaktadır. Bu sorunun giderilmesi amacıyla bu çalışmada, Avrupa'da ekonomik faaliyetlerle ilgili istatistiklerin üretilmesi ve yayılması amacıyla hazırlanan Avrupa Topluluğunda Ekonomik Faaliyetlerin İstatistiki Sınıflamasını (NACE Rev.2, 2013) esas alan ve İspanya Patent ve Marka Ofisi tarafından hazırlanan tasarım tescil başvuru verilerinin sektörel sınıflandırıldığı Locarno-NACE uyum tablosu ${ }^{8}$ kullanılmıştır. Bu doğrultuda, patent ve faydalı model tescil başvuru verilerinin sektörel sınıflandırma tablosu ${ }^{9}$, Ar-Ge merkezi verileri sektörel sınıflandırma tablosu ${ }^{10}$, TURQUALITY programı verileri sektörel sinıflandırma tablosu ${ }^{11}$ ve ihracat verileri sektörel sinıflandırma tablosu ${ }^{12}$,İspanya Patent ve Marka Ofisi tarafından hazırlanmış olan tasarım-endüstriyel sınıflandırma uyum tablosu(NACE Rev.2) ${ }^{13}$ ile uyumlaştırılmıştır.

$\mathrm{Bu}$ doğrultuda, bu çalışmada kullanılan bütün verileri kapsayan ve NACE sınıflandırmasına göre sektörel olarak sinıflandıran "Sektörel Sınıflandırma Sistemlerini Eşleştirme Tablosu" oluşturulmuştur. TURQUALITY programı 2007 yılı ve sonrasında, Ar-Ge merkezleri desteği de 2008 yılı ve sonrasında uygulanmaya başladığı için söz konusu analizler 2008-2015 dönemi için gerçekleştirilmiştir.

Patent, faydalı model ve tasarım tescil başvuru verileri, Ar-Ge merkezi verileri, TURQUALTIY verileri ve ihracat verilerine ait sınıflandırma sistemlerinin birbirleriyle ilişkisi ve uyumu Tablo 1'de gösterilmiştir.

Tablo I: Sektörel Sınıflandırma Sistemlerini Eşleştirme Tablosu

\begin{tabular}{|c|c|c|c|c|}
\hline \multicolumn{5}{|c|}{ SEKTÖR SINIFLANDIRMA SISTEMLERINİ EŞLEŞTİRME TABLOSU } \\
\hline $\begin{array}{l}\text { Analizlerde } \\
\text { Kullanılan } \\
\text { Sektörel } \\
\text { Sinıflandırma }\end{array}$ & $\begin{array}{l}\text { Patent, Faydalı } \\
\text { Model ve Tasarım } \\
\text { Tescil Başvuru } \\
\text { Sınıflandırması }\end{array}$ & $\begin{array}{l}\text { Ar-Ge Merkezi } \\
\text { Sinıflandırması }\end{array}$ & $\begin{array}{c}\text { TURQUALTIY } \\
\text { Programı } \\
\text { Sinıflandırması }\end{array}$ & İhracat Sinıflandırması \\
\hline Gıda ve İçecek & $\begin{array}{l}\text { Gıda Ürünlerinin } \\
\text { İmalatı } \\
\text { İçeceklerin İmalatı }\end{array}$ & Gida Sanayi & $\begin{array}{c}\text { Gastronomi } \\
\text { İşlenmiş Tarım } \\
\text { Ürünleri }\end{array}$ & $\begin{array}{l}\text { Bitkisel Ürünler } \\
\text { Hayvansal Ürünler }\end{array}$ \\
\hline $\begin{array}{l}\text { Tekstil ve } \\
\text { Giyim }\end{array}$ & $\begin{array}{l}\text { Tekstil Ürünlerinin } \\
\text { İmalatı } \\
\text { Giyim Eşyalarının } \\
\text { İmalatı }\end{array}$ & Tekstil & $\begin{array}{l}\text { Hazır Giyim } \\
\text { Tekstil } \\
\text { Deri ve Deri } \\
\text { Mamulleri }\end{array}$ & $\begin{array}{c}\text { Tekstil ve Hammaddeleri } \\
\text { Deri ve Deri Mamulleri } \\
\text { Halı } \\
\text { Hazır Giyim ve Konf. }\end{array}$ \\
\hline
\end{tabular}

8 İspanya Patent ve Marka Ofisi, Concordance with Classification of Locarno and NACE, 2013

9 Patent ve faydalı model tescil başvuru verileri Schmoch ve diğ. (2003) tarafından hazırlan patent-endüstriyel sınıflandırma uyum tablosu kullanılarak sektörel bazda (NACE Rev. 1.1) hesaplanmıştır.

10 https://btgm.sanayi.gov.tr/Handlers/DokumanGetHandler.ashx?dokumanId=3cc49230-9bb0-4a6f-bbedc73edd204594

11 https://www.turquality.com/

12 https://tim.org.tr/tr/ihracat-rakamlari

13 İspanya Patent ve Marka Ofisi, Concordance with Classification of Locarno and NACE, 2013 


\begin{tabular}{|c|c|c|c|c|}
\hline Kimya ve İlaç & $\begin{array}{c}\text { Kimyasalların ve } \\
\text { Kimyasal Ürünlerin İ. } \\
\text { Temel Eczacıllk } \\
\text { Ürünleri ve Eczacilığa } \\
\text { İlişkin Mal. İ. } \\
\text { Kauçuk ve Plastik } \\
\text { Ürünlerin İ }\end{array}$ & $\begin{array}{c}\text { Kimya } \\
\text { İlaç } \\
\text { Kozmetik }\end{array}$ & $\begin{array}{c}\text { Kimya } \\
\text { Plastik Ürünler } \\
\text { Tibbi Cihaz }\end{array}$ & $\begin{array}{l}\text { Kimyevi Maddeler ve } \\
\text { Mamulleri }\end{array}$ \\
\hline $\begin{array}{l}\text { Demir ve } \\
\text { Demir Dışı } \\
\text { Metaller }\end{array}$ & $\begin{array}{c}\text { Ana Metal Sanayi } \\
\text { Fabrikasyon Metal } \\
\text { Ürünleri İmalatı }\end{array}$ & $\begin{array}{l}\text { Demir ve demir } \\
\text { dişı metaller }\end{array}$ & $\begin{array}{l}\text { Ana Metal Sanayi } \\
\text { Metal Ürünleri }\end{array}$ & $\begin{array}{l}\text { Demir ve demir dişı metaller, } \\
\text { Çelik }\end{array}$ \\
\hline $\begin{array}{l}\text { Yazılım, } \\
\text { Bilişim ve } \\
\text { Elektronik }\end{array}$ & $\begin{array}{c}\text { Bilgisayarların, } \\
\text { Elektronik ve Optik } \\
\text { Ürünlerin İmalatı } \\
\text { Elektrikli Teçhizat İ. }\end{array}$ & $\begin{array}{c}\text { Yazılım Biliş̧im, } \\
\text { Bilgi ve İletişim } \\
\text { Tek. } \\
\text { Elektrik- } \\
\text { Elektronik }\end{array}$ & Elektrik Elektronik & Elektrik Elektronik ve Hizmet \\
\hline $\begin{array}{l}\text { Makine ve } \\
\text { Teçhizat }\end{array}$ & $\begin{array}{c}\text { Başka Yerde } \\
\text { Sınıflandırılmamış } \\
\text { Makine ve Ekipman İ. }\end{array}$ & $\begin{array}{c}\text { Makine ve } \\
\text { Teçhizat İmalatı }\end{array}$ & Makine & $\begin{array}{c}\text { Makine ve Aksamları } \\
\text { İklimlendirme San. } \\
\text { Savunma ve Havacılık Sanayi }\end{array}$ \\
\hline Otomotiv & $\begin{array}{c}\text { Motorlu Kara Taşıtları, } \\
\text { Treyler ve Yarı Treyler } \\
\text { İmalatı }\end{array}$ & $\begin{array}{c}\text { Otomotiv Yan } \\
\text { Sanayi } \\
\text { Otomotiv } \\
\text { Otomotiv } \\
\text { Tasarım ve Müh. }\end{array}$ & $\begin{array}{l}\text { Otomotiv-Ana } \\
\text { Sanayi } \\
\text { Otomotiv-Yan Sanayi }\end{array}$ & Otomotiv Endüstri \\
\hline Mobilya & Mobilya İmalatı & Mobilya & Mobilya & Mobilya, Kâğıt ve Orman Ü. \\
\hline
\end{tabular}

Kaynak: Yazar tarafından oluşturulmuştur.

\subsection{Veriler}

2008-2015 dönemine ait patent, faydalı model ve tasarım tescil başvuru verilerinin "Sektörel Sınıflandırma Sistemlerini Eşleştirme Tablosuna” göre uyumlaştırılmış hali Tablo 2'de, Tablo 3'de ve Tablo 4'de gösterilmiştir.

Tablo 2: Patent Tescil Başvuru Verileri Tablosu 2008-2015

\begin{tabular}{|c|c|c|c|c|c|c|c|c|c|}
\hline Sektör Tanımı & స్రి & ర్రి & 䓵 & 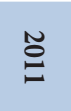 & 苍 & 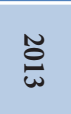 & 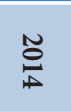 & 苍 & $\frac{\vec{\theta}}{\frac{\overrightarrow{0}}{\hat{E}}}$ \\
\hline Gida ve İçecek & 72 & 60 & 62 & 92 & 140 & 145 & 155 & 176 & 902 \\
\hline Tekstil ve Giyim & 34 & 18 & 30 & 36 & 36 & 43 & 35 & 65 & 297 \\
\hline Kimya ve İlaç & 236 & 283 & 369 & 504 & 686 & 665 & 717 & 704 & 4164 \\
\hline Demir ve Demir Dışı Metaller & 141 & 147 & 204 & 258 & 277 & 279 & 331 & 352 & 1989 \\
\hline Yazılım, Bilişim ve Elektronik & 581 & 610 & 906 & 1093 & 1311 & 1308 & 1518 & 1941 & 9268 \\
\hline Makine ve Teçhizat & 368 & 458 & 563 & 809 & 861 & 812 & 1027 & 1188 & 6086 \\
\hline Otomotiv & 113 & 119 & 145 & 278 & 264 & 303 & 409 & 516 & 2147 \\
\hline Mobilya & 76 & 84 & 103 & 115 & 154 & 127 & 169 & 174 & 1002 \\
\hline
\end{tabular}

Kaynak: Türk Patent ve Marka Kurumu, n.d. 
Tablo 3: Faydalı Model Tescil Başvuru Verileri Tablosu 2008-2015

\begin{tabular}{|c|c|c|c|c|c|c|c|c|c|}
\hline & \multicolumn{9}{|c|}{ Faydalı Model Tescil Başvuru Verileri } \\
\hline Sektör Tanımı & స్రి & ర్రి & 응 & 苂 & 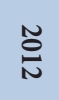 & $\underset{\omega}{\tilde{\omega}}$ & $\underset{\perp}{\stackrel{D}{\Delta}}$ & 苍 & $\frac{\overrightarrow{0}}{\frac{0}{0}}$ \\
\hline Gıda ve İçecek & 13 & 9 & 12 & 9 & 22 & 16 & 30 & 25 & 136 \\
\hline Tekstil ve Giyim & 52 & 33 & 34 & 46 & 69 & 51 & 46 & 41 & 372 \\
\hline Kimya ve İlaç & 272 & 259 & 265 & 251 & 305 & 225 & 254 & 261 & 2092 \\
\hline Demir ve Demir Dışı Metaller & 418 & 352 & 390 & 434 & 411 & 395 & 420 & 399 & 3219 \\
\hline Yazılım, Bilişimve Elektronik & 707 & 662 & 717 & 711 & 942 & 916 & 872 & 905 & 6432 \\
\hline Makine ve Teçhizat & 698 & 665 & 632 & 663 & 874 & 761 & 811 & 798 & 5902 \\
\hline Otomotiv & 129 & 135 & 133 & 138 & 161 & 139 & 149 & 149 & 1133 \\
\hline Mobilya & 331 & 330 & 337 & 381 & 410 & 384 & 346 & 319 & 2838 \\
\hline
\end{tabular}

Kaynak: Türk Patent ve Marka Kurumu, n.d.

Tablo 4: Tasarım Tescil Bașvuru Verileri Tablosu 2008-2015

\begin{tabular}{|c|c|c|c|c|c|c|c|c|c|}
\hline & \multicolumn{9}{|c|}{ Tasarım Tescil Başvuru Verileri } \\
\hline Sektör Tanımı & ర్రి & ฮั & 릉 & 弚 & 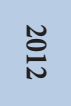 & $\underset{\omega}{\stackrel{0}{\omega}}$ & 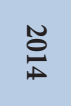 & 苍 & $\frac{\overrightarrow{e^{0}}}{\hat{\vec{E}}}$ \\
\hline Gıda ve İçecek & 49 & 35 & 55 & 46 & 73 & 98 & 84 & 100 & 540 \\
\hline Tekstil ve Giyim & 445 & 433 & 452 & 477 & 592 & 569 & 492 & 470 & 3930 \\
\hline Kimya ve İlaç & 407 & 405 & 412 & 490 & 496 & 468 & 531 & 484 & 3693 \\
\hline Demir ve DemirDışı Metaller & 842 & 886 & 917 & 1106 & 987 & 1005 & 999 & 1062 & 7804 \\
\hline Yazılım, Bilișim ve Elektronik & 472 & 496 & 612 & 713 & 628 & 606 & 578 & 565 & 4670 \\
\hline Makine ve Teçhizat & 1257 & 1159 & 1418 & 1626 & 1590 & 1733 & 2085 & 2036 & 12904 \\
\hline Otomotiv & 71 & 58 & 74 & 85 & 87 & 106 & 90 & 128 & 699 \\
\hline Mobilya & 1044 & 991 & 1104 & 1309 & 1294 & 1432 & 1783 & 1692 & 10649 \\
\hline
\end{tabular}

Kaynak: Türk Patent ve Marka Kurumu, n.d.

2008-2015 dönemine ait Ar-Ge Merkezi verilerinin (Kümülatif) ve TURQUALITY verilerinin "Sektörel Sınıflandırma Sistemlerini Eşleştirme Tablosuna” göre uyumlaştırılmış hali Tablo 5’de ve Tablo 6'da gösterilmiştir.

Tablo 5: AR-GE Merkezleri Verileri (Kümülatif) Tablosu 2008-2015

\begin{tabular}{|c|c|c|c|c|c|c|c|c|c|}
\hline \multirow[b]{2}{*}{ Sektör Tanımı } & \multicolumn{9}{|c|}{ AR-GE Merkezleri Verileri (Kümülatif) } \\
\hline & స్రి & స్రి & 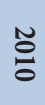 & 苍 & $\stackrel{\text { N }}{\stackrel{N}{*}}$ & $\underset{\omega}{\stackrel{\omega}{\omega}}$ & $\underset{\mathbb{C}}{\stackrel{\sim}{\Delta}}$ & 苍 & $\frac{\overrightarrow{0}}{\overrightarrow{0}}$ \\
\hline Gida ve İçecek & - & - & - & - & 1 & 3 & 4 & 7 & 15 \\
\hline Tekstil ve Giyim & - & 2 & 3 & 5 & 6 & 7 & 7 & 12 & 42 \\
\hline Kimya ve İlaç & 1 & 5 & 6 & 6 & 9 & 15 & 21 & 27 & 90 \\
\hline Demir ve Demir Dışı Metaller & - & - & - & - & - & - & 2 & 5 & 7 \\
\hline
\end{tabular}




\begin{tabular}{|c|c|c|c|c|c|c|c|c|c|}
\hline Yazılım, Bilişim ve Elektronik & 4 & 10 & 13 & 14 & 18 & 2 & 26 & 42 & 150 \\
\hline Makine ve Teçizat & - & - & 1 & 4 & 6 & 6 & 9 & 14 & 40 \\
\hline Otomotiv & 1 & 15 & 23 & 33 & 42 & 44 & 49 & 67 & $\mathbf{2 7 4}$ \\
\hline Mobilya & - & - & - & 1 & - & - & - & 2 & $\mathbf{3}$ \\
\hline
\end{tabular}

Kaynak: T.C. Sanayi ve Teknoloji Bakanlığı, n.d.

Tablo 6: TURQUALTIY Programından Faydalanan Firmaların Uyumlaştırılmış Sektörel Dağılımı

\begin{tabular}{|c|c|c|c|c|c|c|c|c|c|}
\hline \multirow[b]{2}{*}{ Sektör Tanımı } & \multicolumn{9}{|c|}{$\begin{array}{l}\text { TURQUALTIY Programı Kapsamındaki Firmaların } \\
\text { Uyumlaștırılmış Sektörel Dağılımı }\end{array}$} \\
\hline & ஓ્ণ & ஓ्रे & 육 & 글 & 귝 & 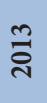 & 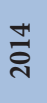 & 묵 & 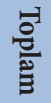 \\
\hline Gıda ve İçecek & - & - & 1 & 1 & 1 & 4 & 4 & 7 & 18 \\
\hline Tekstil ve Giyim & 2 & - & 2 & 3 & 3 & 3 & 4 & 2 & 19 \\
\hline Kimya ve İlaç & 3 & - & 3 & & 3 & 3 & 6 & 4 & 22 \\
\hline Demir ve Demir Dıșı Metaller & 2 & - & & 2 & 2 & 1 & 1 & 2 & 10 \\
\hline Yazılım, Bilişim ve Elektronik & 4 & - & 1 & 2 & 1 & 2 & 1 & 5 & 16 \\
\hline Makine ve Teçhizat & - & - & 1 & - & - & 1 & 1 & 3 & 6 \\
\hline Otomotiv & 1 & - & 2 & 1 & 1 & 4 & 1 & 1 & 11 \\
\hline Mobilya & 4 & - & 1 & 1 & 1 & - & 3 & 2 & 12 \\
\hline
\end{tabular}

Kaynak: TURKQUALITY, n.d.

\section{I. Bulgular}

Bu çalışmada ulaşılan bulgular “Sektörel Sınıflandırma Sistemlerini Eşleştirme Tablosunda” yer alan sekiz sektör özelinde analiz edilmiştir.

Bu kapsamda, Türkiyede imalat sanayinin alt sektörlerinin tamaminda yapılan patent tescil başvurularının \%3,5’i, faydalı model tescil başvurularının \%0,61'i ve tasarım tescil başvurularının \%1,2’si “Gıda ve İçecek” sektöründe yer almaktadır. Söz konusu sekiz sektörün tamamında faaliyet gösteren Ar-Ge merkezlerinin sadece \%2,41’i “Gıda ve İçecek” sektöründe yer almaktadır. “Gıda ve İçecek” sektörünün TURQUALITY programından faydalanma oranı ise \%15,79'dur."Gıda ve İçecek” sektöründe gerçekleşen ihracat ile bu sektörde yapılan tasarım tescil başvuruları ve patent tescil başvuruları arasında ciddi bir ilişki olduğu saptanmasına karşın bu sektörde gerçekleşen ihracat ile bu sektörde yapılan faydalı model tescil başvuruları arasında anlamlı bir ilişki saptanamamıştır. 
Şekil I: Gıda ve İçecek Sektöründe Gerçekleşen İhracat ile Yapılan Tasarım Tescil Başvuruları Arasındaki Korelasyon $(r=0,867)$

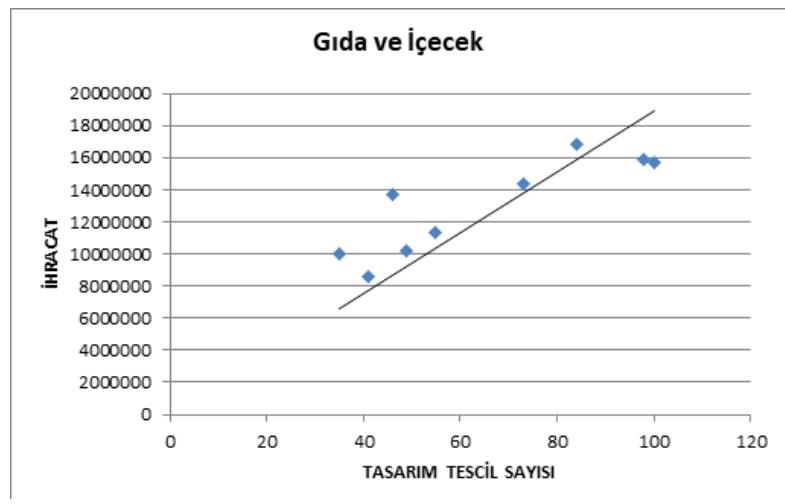

Şekil 2: Gıda ve İçecek Sektöründe Gerçekleşen İhracat ile Yapılan Patent Tescil Başvuruları Arasındaki Korelasyon $(r=0,933)$

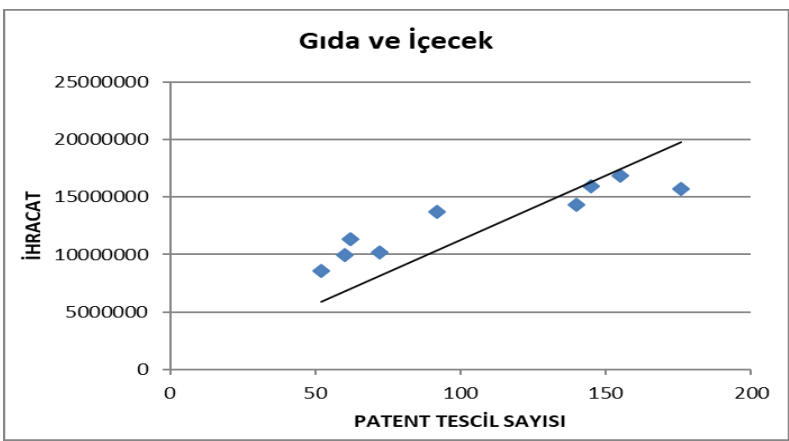

"Gıda ve İçecek" sektörünün TURQUALITY programından faydalanma oranı ile bu sektörde yapılan ihracat arasında ciddi bir ilişki olduğu saptanmıştır. Buna karşın, "Gıda ve İçecek" sektöründe faaliyet gösteren Ar-Ge merkezleri ile bu sektörde yapılan ihracat arasındaki ilişki, Ar-Ge merkezleri verisinin yetersiz olmasından dolayı analiz edilememiştir. 
Şekil 3: Gıda ve İçecek Sektöründe Gerçekleşen İhracat ile TURQUALITY Arasındaki Korelasyon (r = 0,777)

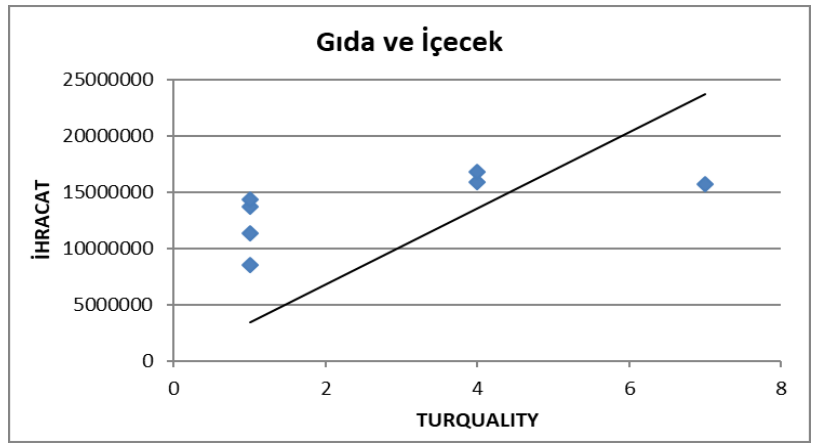

Türkiye'de imalat sanayinin alt sektörlerinin tamamında yapılan patent tescil başvurularının \%1,1’i, faydalı model tescil başvurularının \%1,68’i ve tasarım tescil başvurularının \%8,75’i “Tekstil ve Giyim” sektöründe yer alırken bu sektörlerin tamamında faaliyet gösteren Ar-Ge merkezlerinin sadece \%6,76'sı “Tekstil ve Giyim” sektöründe yer almaktadır. “Tekstil ve Giyim” sektörünün TURQUALITY programından faydalanma oranı ise \%16,67'dir. “Tekstil ve Giyim” sektöründe gerçekleşen ihracat ile bu sektörde yapılan tasarım tescil başvuruları arasında ciddi bir ilişki olduğu saptanmasına karşın bu sektörde gerçekleşen ihracat ile bu sektörde yapılan patent ve faydalı model tescil başvuruları arasında anlamlı bir ilişki saptanamamıştır.

Şekil 4: Tekstil ve Giyim Sektöründe Gerçekleşen İhracat ile Yapılan Tasarım Tescil Başvuruları Arasındaki Korelasyon $(\mathrm{r}=0,867)$

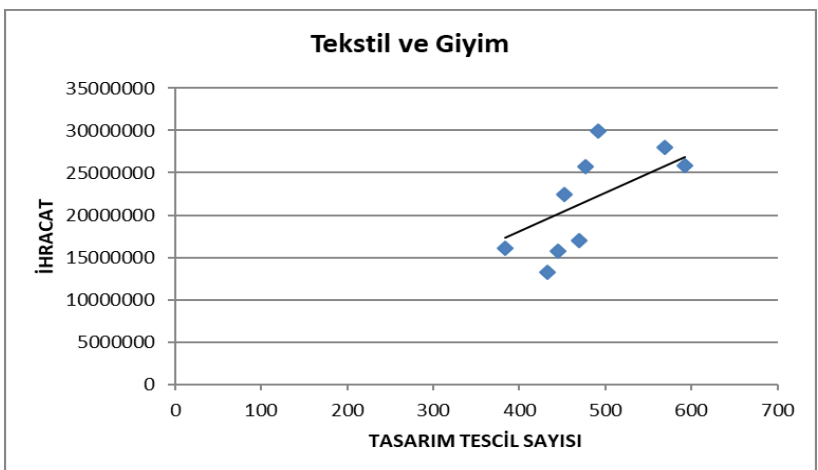

“Tekstil ve Giyim” sektöründe faaliyet gösteren Ar-Ge merkezleri ile bu sektörde yapılan ihracat arasında ciddi bir ilişki olduğu saptanmıştır. Ayrıca, “Tekstil ve Giyim” sektörünün TURQUALITY programından faydalanma oranı ile bu sektörde yapılan ihracat arasında ciddi bir ilişki olduğu saptanmıştır. 
Şekil 5: Tekstil ve Giyim Sektöründe Gerçekleşen İhracat İle Bu Sektörde Faaliyet Gösteren Ar-Ge merkezleri Arasındaki Korelasyon $(r=0,845)$

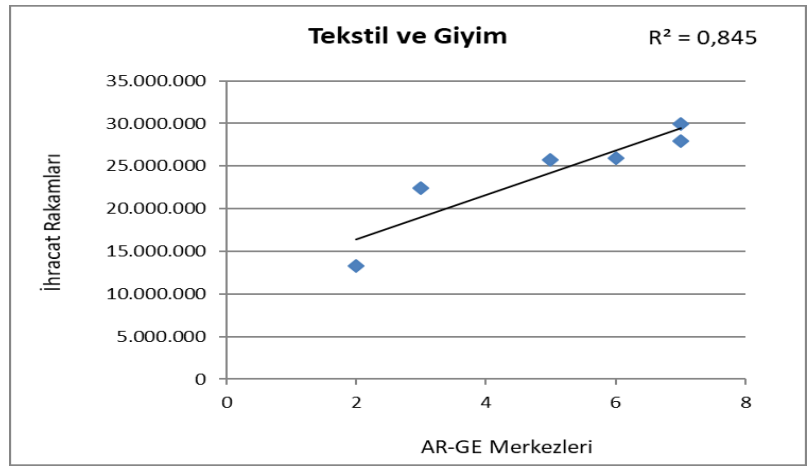

Şekil 6: Tekstil ve Giyim Sektöründe Gerçekleşen İhracat ile TURQUALITY Arasındaki Korelasyon $(r=0,913)$

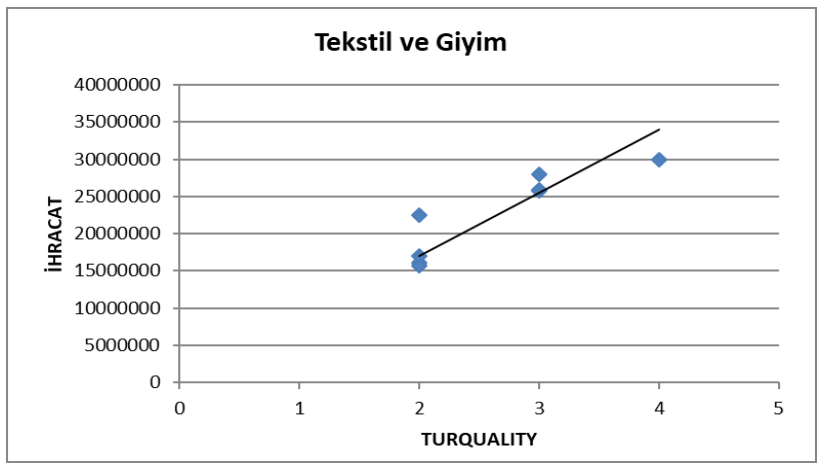

Türkiye’de imalat sanayinin alt sektörlerinin tamamında yapılan patent tescil başvurularının \%16,2'si, faydalı model tescil başvurularının \%9,46'sı ve tasarım tescil başvurularının \%8,22'si "Kimya ve İlaç" sektöründe yer alırken bu sektörlerin tamamında faaliyet gösteren Ar-Ge merkezlerinin \%14,5’i "Kimya ve İlaç" sektöründe yer almaktadır. "Kimya ve İlaç” sektörünün TURQUALITY programından faydalanma oranı ise \%19,3'dür.

"Kimya ve İlaç" sektöründe gerçekleşen ihracat ile bu sektörde yapılan tasarım tescil başvuruları ve patent tescil başvuruları arasında ciddi bir ilişki olduğu saptanmasına karşın bu sektörde gerçekleşen ihracat ile bu sektörde yapılan faydalı model tescil başvuruları arasında anlamlı bir ilişki saptanamamıştır. 
Şekil 7: Kimya ve İlaç Sektöründe Gerçekleşen İhracat ile Yapılan Tasarım Tescil Başvuruları Arasındaki Korelasyon $(r=0,883)$

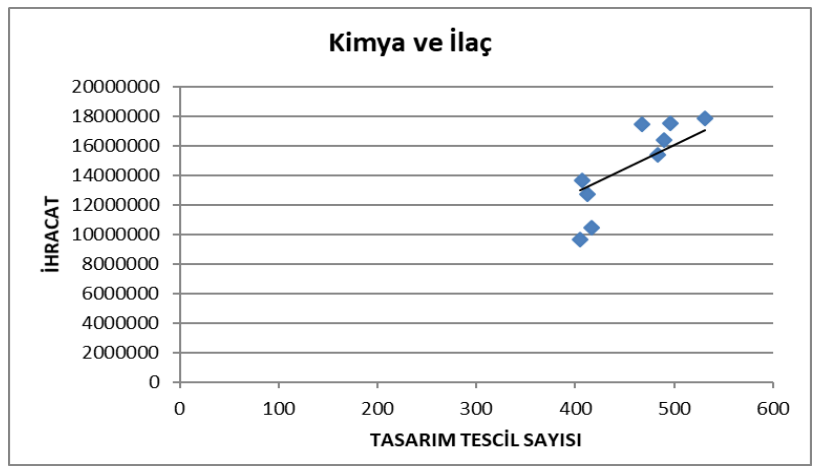

Şekil 8: Kimya ve İlaç Sektöründe Gerçekleșen İhracat ile Yapılan Patent Tescil Başvuruları Arasındaki Korelasyon $(r=0,817)$

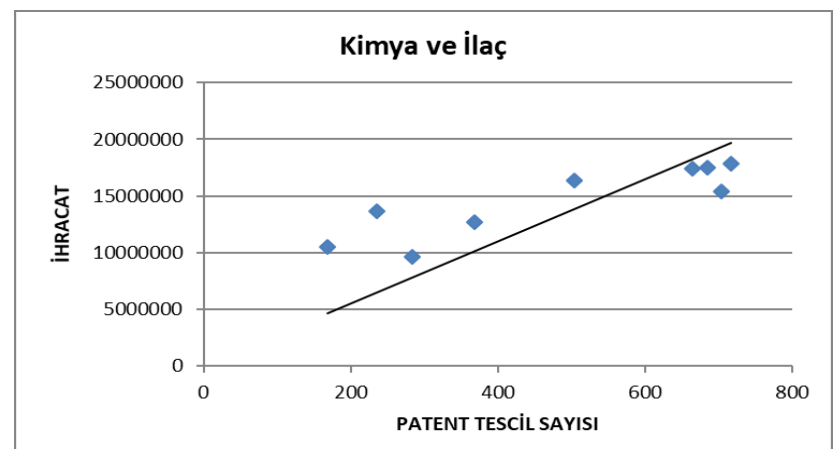

Buna karşın, "Kimya ve İlaç" sektöründe faaliyet gösteren Ar-Ge merkezleri ve bu sektörün TURQUALITY programından faydalanma oranı ile bu sektörde yapılan ihracat arasında anlamlı bir ilişki bulunamamıştır.

Türkiye'de imalat sanayinin alt sektörlerinin tamamında yapılan patent tescil başvurularının \%7,7'si, faydalı model tescil başvurularının \%14,55’i ve tasarım tescil başvurularının \%17,4'ü “Demir ve Demir Dışı Metaller” sektöründe yer almaktadır. Söz konusu sekiz sektörün tamamında faaliyet gösteren Ar-Ge merkezlerinin \%1,13’ü “Demir ve Demir Dışı Metaller” sektöründe yer almaktadır. "Demir ve Demir Dışı Metaller" sektörünün TURQUALITY programından faydalanma oranı \%8,77'dir.“Demir ve Demir Dışı Metaller” sektöründe gerçekleşen ihracat ile bu sektörde yapılan patent, faydalı model ve tasarım tescil başvuruları, bu sektörde faaliyet gösteren Ar-Ge merkezleri ve bu sektörün TURQUALITY programından faydalanma oranı arasında anlamlı bir ilişki bulunamamıştır. 
Türkiyede imalat sanayinin alt sektörlerinin tamamında yapılan patent tescil başvurularının \%35,8’i, faydalı model tescil başvurularının \%29,07’si ve tasarım tescil başvurularının \%10,4'ü "Yazılım, Bilişim ve Elektronik" sektöründe yer alırken bu sektörlerin tamamında faaliyet gösteren Ar-Ge merkezlerinin \%24,15’i "Yazılım, Bilişim ve Elektronik" sektöründe yer almaktadır. "Yazılım, Bilişim ve Elektronik" sektörünün TURQUALITY programından faydalanma oranının \%14,03 dür. "Yazılım, Bilişim ve Elektronik" sektöründe gerçekleşen ihracat ile bu sektörde yapılan patent tescil başvuruları arasında ciddi bir ilişki olduğu saptanmasına karşın bu sektörde gerçekleşen ihracat ile bu sektörde yapılan faydalı model ve tasarım tescil başvuruları arasında anlamlı bir ilişki saptanamamıştır.

Şekil 9: Yazılım, Bilişim ve Elektronik Sektöründe Gerçekleşen İhracat ile Yapılan Patent Tescil Başvuruları Arasındaki Korelasyon $(r=0,733)$

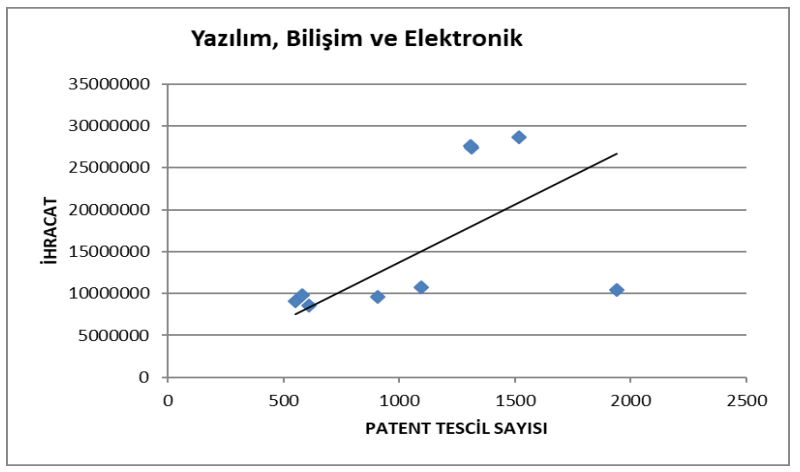

"Yazılım, Bilişim ve Elektronik" sektöründe faaliyet gösteren Ar-Ge merkezleri ve bu sektörün TURQUALITY programından faydalanma oranı ile bu sektörde yapılan ihracat arasında anlamlı bir iliş̧ki bulunamamıştır.

Türkiyede imalat sanayinin alt sektörlerinin tamamında yapılan patent tescil başvurularının $\% 23,5^{\prime} \mathrm{i}$, faydalı model tescil başvurularının $\% 26,68^{\prime} \mathrm{i}$ ve tasarım tescil başvurularının $\% 28,75$ ' $\mathrm{i}$ "Makine ve Teçhizat" sektöründe yer alırken bu sektörlerin tamamında faaliyet gösteren Ar-Ge merkezlerinin \%6,44’ü "Makine ve Teçhizat" sektöründe yer almaktadır. "Makine ve Teçhizat" sektörünün TURQUALITY programından faydalanma oranının ise \%5,26dır. "Makine ve Teçhizat" sektöründe gerçekleșen ihracat ile bu sektörde yapılan tasarım tescil başvuruları ve patent tescil başvuruları arasında ciddi bir ilişki olduğu saptanmasına karşın bu sektörde gerçekleşen ihracat ile bu sektörde yapılan faydalı model tescil başvuruları arasında anlamlı bir ilişki saptanamamıştır. 
Şekil I0: Makine ve Teçhizat Sektöründe Gerçekleşen İhracat ile Yapılan Tasarım Tescil Başvuruları Arasındaki Korelasyon $(r=0,933)$

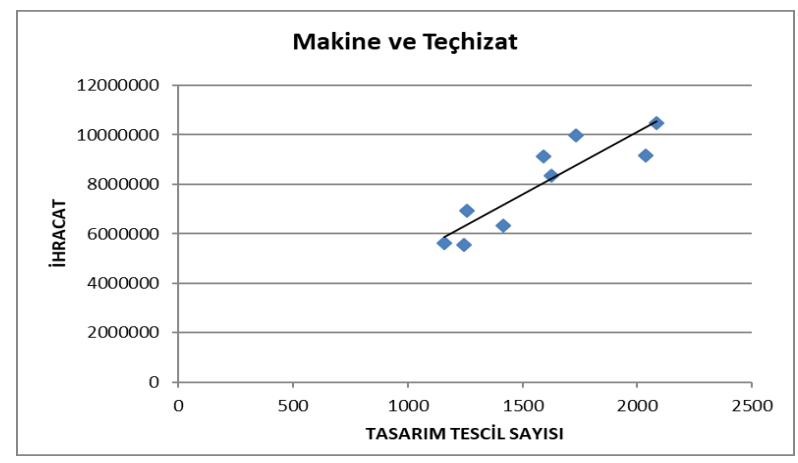

Şekil I I: Makine ve Teçhizat Sektöründe Gerçekleşen İhracat ile Yapılan Patent Tescil Başvuruları Arasındaki Korelasyon $(r=0,867)$

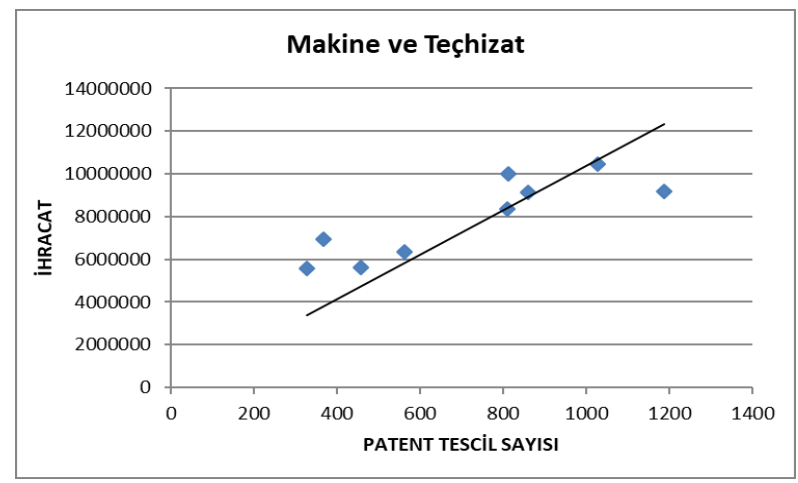

Buna karşın, "Makine ve Teçhizat” sektöründe faaliyet gösteren Ar-Ge merkezleri ve bu sektörün TURQUALITY programından faydalanma oranı ile bu sektörde yapılan ihracat arasında anlamlı bir ilişki bulunamamıștır.

Türkiye'de imalat sanayinin alt sektörlerinin tamamında yapılan patent tescilbaşvurularının \%8,3'ü, faydalı model tescil başvurularının \%5,12'si ve tasarım tescil başvurularının \%1,56'sı “Otomotiv" sektöründe yer alırken bu sektörlerin tamamında faaliyet gösteren Ar-Ge merkezlerinin \%44,12'si "Otomotiv" sektöründe yer almaktadır. "Otomotiv" sektörünün TURQUALITY programından faydalanma oranının \%9,65'dir.“'Otomotiv" sektöründe gerçekleşen ihracat ile bu sektörde yapılan patent, faydalı model ve tasarım tescil başvuruları, bu sektöründe faaliyet gösteren Ar-Ge merkezleri ve bu sektörün TURQUALITY programından faydalanma oranı arasında anlamlı bir ilişki bulunamamıştır. 
Türkiyede imalat sanayinin alt sektörlerinin tamamında yapılan patent tescil başvurularının \% 3,9'u, faydalı model tescil başvurularının \% 12,83'ü ve tasarım tescil başvurularının \%23,72'si "Mobilya" sektöründe yer almaktadır. Söz konusu sekiz sektörün tamamında faaliyet gösteren Ar-Ge merkezlerinin \%0,49'i "Mobilya" sektöründe yer almaktadır. "Mobilya" sektörünün TURQUALITY programından faydalanma oranı ise \% 10,53 'tür. "Mobilya" sektöründe gerçekleşen ihracat ile bu sektörde yapılan tasarım tescil başvuruları ve patent tescil başvuruları arasında ciddi bir ilişki olduğu saptanmasına karşın bu sektörde gerçekleşen ihracat ile bu sektörde yapılan faydalı model tescil başvuruları arasında anlamlı bir ilişki saptanamamıştır.

Şekil I2: Mobilya Sektöründe Gerçekleşen İhracat ile Yapılan Tasarım Tescil Başvuruları Arasındaki Korelasyon $(r=0,883)$

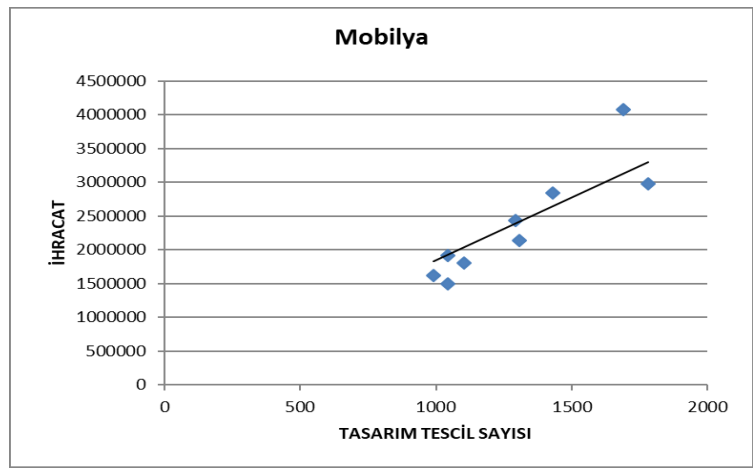

Şekil 13: Mobilya Sektöründe Gerçekleşen İhracat ile Yapılan Patent Tescil Başvuruları Arasındaki Korelasyon $(r=0,933)$

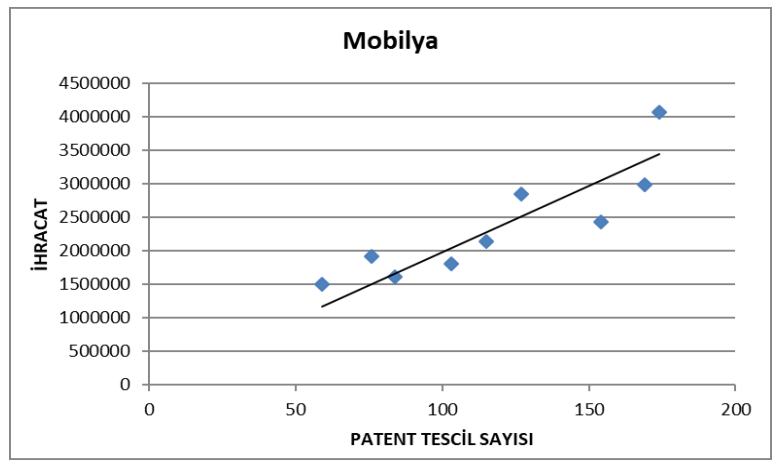

"Mobilya" sektöründe faaliyet gösteren Ar-Ge merkezleri ile yapılan ihracat arasında anlamlı bir ilişki olmasına karşın "Mobilya" sektörünün TURQUALITY programından faydalanma oranı ile bu sektörde yapılan ihracat arasında anlamlı bir ilişki bulunamamıştır. 
Şekil I4: Mobilya Sektöründe Gerçekleşen İhracat İle Bu Sektörde Faaliyet Gösteren Ar-Ge merkezleri Arasındaki Korelasyon $(\mathrm{r}=0,796)$

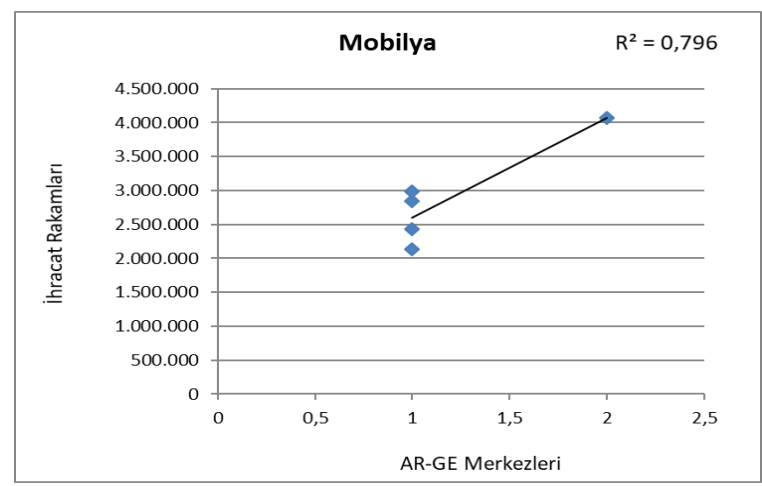

\section{Sonuç ve Öneriler}

Bu çalışmada "Analizlerde Kullanılacak Sektörel Sınıflandırma” başlığı altında yer alan sekiz sektörde faaliyet gösterenAr-Ge merkezleri ile bu sektörlerin TURQUALITY programından faydalanma oranları, bu sektörlerin tasarım, patent ve faydalı model tescil başvuru oranları ve bu sektörlerin ihracat oranları analiz edildiğinde söz konusu sekiz sektörün birbirlerinden farklı davranışlar sergiledikleri görülmüştür.

Tescil başvuruları kapsamında bakıldığında, "Kimya ve İlaç" ile "Yazılım, Bilişim ve Elektronik" sektörlerinin patent yoğun sektörler, "Demir ve Demir Dişı Metaller" ile "Mobilya" sektörlerinin ise tasarım yoğun sektörler oldukları saptanmıştır. "Makine ve Teçhizat" sektörünün ise hem patent hem de tasarım yoğun bir sektör olduğu saptanmıştır.

Patent yoğun olan "Kimya ve İlaç" ile "Yazılım, Bilişim ve Elektronik" sektörlerinde faaliyet gösteren Ar-Ge merkezleri sayısının oldukça yüksek olduğu saptanmıştır. Bununla birlikte, "Kimya ve İlaç" sektörünün TURQUALITY programından faydalanma oranının da oldukça yüksek olduğu saptanmıştır. Buna karşın, "Yazılım, Bilişim ve Elektronik" sektörünün TURQUALITY programından faydalanma oranının orta seviyede olduğu saptanmıștır. Ancak, patent yoğun olan "Kimya ve İlaç" ile "Yazılım, Bilişim ve Elektronik" sektörlerinde faaliyet gösteren Ar-Ge merkezleri ve bu sektörlerin TURQUALITY programından faydalanma oranları ile ihracat arasında anlamlı bir ilişki bulunamamıştır. Ayrıca, patent yoğun olan "Kimya ve İlaç" ile "Yazılım, Bilişim ve Elektronik" sektörlerinde yapılan patent tescil başvuru sayıları ile ihracat arasında güçlü bir ilişki olduğu analiz edilmiştir.

Tasarım yoğun olan "Demir ve Demir Dışı Metaller” ile "Mobilya” sektörlerinde faaliyet gösteren Ar-Ge merkezleri sayısının oldukça düşük olduğu saptanmıştır. Bununla birlikte, "Demir ve Demir Dışı Metaller" ile "Mobilya” sektörlerinin TURQUALITY programından faydalanma 
oranlarının orta seviyede olduğu saptanmıştır. Ayrıca, tasarım yoğun olan "Mobilya" sektöründe faaliyet gösteren Ar-Ge merkezleri ile ihracat arasında güçlü bir ilişki olduğu analiz edilmiştir. Ancak, bir diğer tasarım yoğun olan "Demir ve Demir Dışı Metaller" sektöründe faaliyet gösteren Ar-Ge merkezleri ile ihracat arasında anlamlı bir ilişki bulunamamıştır. Ayrıca, "Demir ve Demir Dışı Metaller" ile "Mobilya" sektörlerinin TURQUALITY programından faydalanma oranları ile ihracat arasında anlamlı bir ilişki bulunamamıştır. Ayrıca, tasarım yoğun olan "Mobilya" sektöründe yapılan tasarım tescil başvuru sayıları ile ihracat arasında güçlü bir ilişki olduğu ortaya konurken, bir diğer tasarım yoğun olan "Demir ve Demir Dışı Metaller" sektöründe yapılan tasarım tescil başvuru sayıları ile ihracat arasında anlamlı bir ilişki bulunamamıştır.

Hem patent hem de tasarım yoğun olan "Makine ve Teçhizat" sektöründe faaliyet gösteren Ar-Ge merkezleri sayısının orta seviyede olduğu saptanmıştır. Ancak, "Makine ve Teçhizat" sektörünün TURQUALITY programından faydalanma oranının düşük seviyede olduğu saptanmıştır. Ayrıca, "Makine ve Teçhizat" sektöründe faaliyet gösteren Ar-Ge merkezleri ve bu sektörün TURQUALITY programından faydalanma oranı ile ihracat arasında anlamlı bir ilişki bulunamamıștır. Ancak, "Makine ve Teçhizat" sektöründe yapılan tasarım ve patent tescil başvuru sayıları ile ihracat arasında güçlü bir ilişki olduğu analiz edilmiştir.

"Analizlerde Kullanılacak Sektörel Sınıflandırma” başlı̆̆ı altında yer alan sekiz sektör, tescil başvuru sayıları kapsamında değerlendirildiğinde söz konusu sektörlerin gelişmişlik düzeylerinin farklı olduğu, devlet desteklerinden faydalanma düzeyleri ile tercihlerinin farklı olduğu ve ürettikleri katma değerin diğer bir ifadeyle ihracatın da farklı olduğu saptanmıştır. Ayrıca, söz konusu sekiz sektörde faaliyet gösteren Ar-Ge merkezleri ve bu sektörlerin TURQUALITY programından faydalanma oranları ile bu sektörlerde yapılan ihracat arasındaki ilişkinin şiddeti de birbirlerinden farklılık göstermektedir.

$\mathrm{Bu}$ çalışmada iki tespit yapılmıştır. Bu tespitlerden ilki, bu çalışma konusunu oluşturan verilerin analiz edilmesi esnasında söz konusu verilerin sınıflandırılmasında birbirinden tamamen farklı yöntem ve amaca sahip sınıflandırma sistemlerinin kullanılmış olmasıdır. Bu durum, devlet desteklerinin yönetiminde bir birliktelik/ortak akıl olmadığını ortaya koymaktadır. Ayrıca, söz konusu verilerin tasnifinin belirli bir sistematiğe sahip olmamasının ileride bu verilerin analizini de zorlaştıracağı ortadadır.

Türkiyede verilen teşviklerin etki analizlerinin yapılabilmesi için bu alanda tutulan istatistiklerin ekonomik faaliyetlerin sinıflandırılmasında kullanılan bir sistemi olan NACE’ye göre yapılması gerekmektedir. "Avrupa Topluluğunda Ekonomik Faaliyetlerin İstatistiki Sınıflaması (NACE)",Avrupada ekonomik faaliyetlere ilişkin istatistiklerin toplanması, tasnif edilmesi ve yayılması amacını taşıyan bir başvuru sistemidir.

Bir diğer tespit ise bu çalışmada "Analizlerde Kullanılacak Sektörel Sınıflandırma" başlığı altında yer alan sekiz sektörde faaliyet gösteren Ar-Ge merkezleri ve bu sektörlerin TURQUALITY programından faydalanma oranları ile bu sektörlerde yapılan patent, faydalı model ve tasarım tescil başvuruları ile ihracat arasındaki ilişkinin hem yönünün hem de şiddetinin de birbirlerinden 
farklılık gösteriyor olmasıdır. Bu bağlamda, Türkiye'de imalat sanayinin alt sektörlerinin yapıları ve davranış şekillerinin birbirlerinden farklı olduğu sonucuna varılmıştır.

OECD’nin (2008) yapmış olduğu sınıflandırmaya göre düşük teknoloji grubunda yer alan "Gıda ve İçecek” sektöründe gerçekleşen patent tescil başvurularının \%3,5, faydalı model tescil başvurularının \%0,61 ve tasarım tescil başvurularının \%1,2 olması beklenen bir sonuç olarak karşımıza çıkmaktadır. Ayrıca “Gıda ve İçecek” sektöründe faaliyet gösteren Ar-Ge merkezlerinin \%2,41 olması “Gıda ve İçecek” sektörünün düşük teknoloji grubunda yer alan bir sektör olduğunu ispatlamaktadır. Buna karşın, düşük teknolojili diğer bir ifadeyle katma değeri düşük olan "Gıda ve İçecek” sektörünün TURQUALITY programından faydalanma oranının \%15,79 olması çarpıcı bir sonuç olarak karşımıza çıkmaktadır.

Benzer bir durum düşük teknoloji grubunda yer alan “Tekstil ve Giyim” sektörü için de karşımıza çıkmaktadır. “Tekstil ve Giyim” sektöründe gerçekleşen patent tescil başvurularının \%1,1, faydalı model tescil başvurularının \%1,68 ve tasarım tescil başvurularının \%8,75 olması beklenen bir sonuç olarak karşımıza çıkmaktadır. Ayrıca “Tekstil ve Giyim” sektöründe faaliyet gösteren Ar-Ge merkezlerinin \%6,76 olması “Tekstil ve Giyim” sektörünün düşük teknoloji grubunda yer alan bir sektör olduğunu ispatlamaktadır. Buna karşın, düşük teknolojili diğer bir ifadeyle katma değeri düşük olan “Tekstil ve Giyim” sektörünün TURQUALITY programından faydalanma oranının \%16,67 olması çarpıcı bir sonuç olarak karşımıza çıkmaktadır.

"Gıda ve İçecek” ile “Tekstil ve Giyim” sektörlerinde ortaya çıkan bu şaşırtıcı duruma kıyasla "Kimya ve İlaç" ile "Yazılım, Bilişim ve Elektronik" sektörlerinde daha beklendik ve daha sağlıklı çalışan bir sektör yapısıyla karşılaşıldığını söyleyebiliriz.

OECD’nin (2008) yapmış olduğu sınıflandırmaya göre yüksek teknoloji grubunda yer alan "Kimya ve İlaç" sektöründe gerçekleşen patent tescil başvurularının \%16,2, faydalı model tescil başvurularının \%9,46 ve tasarım tescil başvurularının \%8,22 olması beklenen bir sonuç olarak karşımıza çıkmaktadır. Ayrıca "Kimya ve İlaç” sektöründe faaliyet gösteren Ar-Ge merkezlerinin \%14,5 olması "Kimya ve İlaç” sektörünün yüksek teknoloji grubunda yer alan bir sektör olduğunu ispatlamaktadır. Bununla birlikte, yüksek teknolojili diğer bir ifadeyle katma değeri yüksek olan "Kimya ve İlaç" sektörünün TURQUALITY programından faydalanma oranının \%19,3 olması bu sektör özelinde beklenen bir sonuç olarak karşımıza çıkmaktadır.

Yüksek teknoloji grubunda yer alan "Yazılım, Bilişim ve Elektronik” sektöründe ise gerçekleşen patent tescil başvurularının \%35,8, faydalı model tescil başvurularının \%29,07 ve tasarım tescil başvurularının \%10,4 olması beklenen bir sonuç olarak karşımıza çıkmaktadır. Ayrıca "Yazılım, Bilişim ve Elektronik" sektöründe faaliyet gösteren Ar-Ge merkezlerinin \%24,15 olması "Yazılım, Bilişim ve Elektronik” sektörünün yüksek teknoloji grubunda yer alan bir sektör olduğunu ispatlamaktadır. Bununla birlikte, yüksek teknolojili diğer bir ifadeyle katma değeri yüksek olan "Yazılım, Bilişim ve Elektronik" sektörünün TURQUALITY programından faydalanma oranının \%14,03 olması bu sektör özelinde çok yüksek bir oran olmasa da beklenen bir sonuç olarak karşımıza çıkmaktadır. 
"Otomotiv" sektöründe ise durum diğer sektörlere göre biraz daha farklıdır. OECD’nin (2008) yapmış olduğu sinıflandırmaya göre orta-yüksek teknoloji grubunda yer alan "Otomotiv" sektöründe gerçekleşen patent tescil başvurularının \%8,3, faydalı model tescil başvurularının $\% 5,12$ ve tasarım tescil başvurularının \%1,56 olması çarpıcı bir sonuç olarak karşımıza çıkmaktadır. Çünkü orta-yüksek teknoloji grubunda yer alan "Otomotiv" sektöründe patent, faydalı model ve tasarım tescil başvuru oranlarının daha yüksek olması beklenmektedir. Bu durum, "Otomotiv" sektöründe fikri mülkiyet haklarının yabancı kaynaklı olduğunu göstermekte ve ülkemizde otomotiv sektörünün yan sanayi alanında yoğunlaştığı gerçeğiyle örtüşmektedir. "Otomotiv" sektöründe gerçekleşen patent, faydalı model ve tasarım tescil başvuru oranlarının çok düşük olmasına karşın bu sektörde faaliyet gösteren Ar-Ge merkezlerinin \%44,12 olması "Otomotiv" sektörünün patent, faydalı model ve tasarım tescil başvuru performansının çok düşük olduğunu ortaya koymaktadır. Bununla birlikte, yüksek teknolojili diğer bir ifadeyle katma değeri yüksek olan "Otomotiv" sektörünün TURQUALITY programından faydalanma oranının \%9,65 olması bu sektör özelinde oldukça düşük bir sonuç olarak karşımıza çıkmaktadır.

Düşük teknoloji grubunda yer alan "Gıda ve İçecek" ile “Tekstil ve Giyim” sektörlerinin TURQUALITY programından yüksek oranda faydalanmalarına karşın orta-yüksek teknoloji grubunda yer alan ve Türkiyede faaliyet gösteren Ar-Ge merkezlerinin neredeyse yarısının faaliyet gösterdiği "Otomotiv" sektörünün TURQUALITY programından yeterli seviyede faydalanamaması, yüksek katma değerli ihracat temelli büyümeyi kendisine hedef edinen Türkiye’nin kaynaklarını verimli kullanmadığını ortaya koymaktadır. Ayrıca, bir ihracat desteği olan TURQUALITY programının bu anlamda tam olarak doğru sektörlere kanalize edilemediğini de söylemek mümkündür.

Bu kapsamda, devlet desteklerinin oluşturulma ve uygulanma sürecinde Türkiye'de imalat sanayinin alt sektörlerinin karakterlerinin göz önünde bulundurularak hareket edilmesinin kamu kaynaklarının etkin kullanılmasını sağlamak amacıyla gerekli olduğu ortadadır.

Ülkemizdeki uygulamaların aksine gelişmiş ülkelerde yerel yönetimler, sivil toplum kuruluşları, ticaret ve sanayi odaları uygulanan desteklerde aktif rol almakta ve devlet desteklerin doğru alanlara kanalize edilmesine sağlamaktadır. Tam da bu sebepten dolayı, Türkiyede merkezi yönetimin tek başına sadece makroekonomik parametreleri göz önünde bulundurarak hazırladıkları teşvik programları başarısız olmaktadır (DPT, 2007).

Dünyada hızlı kalkınma başarısı gösteren ülkelere baktığımızda birçoğunun bu başarısında kalkınma stratejilerinde uyguladıkları başarılı teşvik politikalarının olduğunu görmekteyiz. İhracata dayalı büyüme modelini benimseyen ve bir dönem Türkiye ile benzer ekonomik göstergelere sahip olan Güney Kore ve İlandảnın yakaladığı büyüme rakamları değerlendirdiğinde Türkiye’nin neleri eksik veya yanlış yaptığı net bir şekilde ortaya çımaktadır.

Güney Kore’nin uygulandığı teşvik politikalarında başarılı olmasının altında yatan sebeplere baktığımızda, söz konusu politikaların akılcı, kapsayıcı ve uzun vadeli oldukları görülmektedir. Ayrıca, uygulanan teşviklerin belirli bir sayıda tutulması, performanslarının incelemesinde ve 
denetlenmesinde çok büyük bir öneme sahiptir. Güney Kore’de doğru sayıda ve doğru süreliğine, belirli kriterler ve kurallar kapsamında uygulanan teşvikler ekonomi için büyük kazanımlar sağlamıştır (Akdeve ve Karagöl, 2013).

İrlanda, teşvik uygulamalarında başarılı olan bir diğer ülke olarak, 1960'lardan sonra ithal ikameci politikalardan vazgeçmiş ve yabancı sermayeyi çekmeyi amaçlayan ve rekabet ortamını besleyen politikalar izlemeye başlamıştır. İrlanda’da uygulanan teşvikler sektör bazlı olmayıp proje bazlıdır ve öncelikli olarak yüksek teknolojili, katma değeri yüksek ve ihracat potansiyeli olan sektörlere uygulanmıştır (Eser, 2011).İrlandảnın uyguladığı teşvik sisteminin en büyük özelliği ise yüksek katma değerli, teknoloji yoğun yabacı sermayeyi kendisine çeken bir yapıya sahip olmasıdır (Özcan, 2008).

Büyük bir kalkınma başarısı gösteren ülkelerin bu başarılarının altında uyguladıkları etkili teşvik politikalarının olduğu çok açıktır. Güney Kore ve İrlanda’nın kalkınmalarında büyük bir öneme sahip olan teşvik politikalarına bakıldığında her iki ülkenin de teşvik uygulamalarında iki ortak özellik olduğu görülmektedir. Bunlar;

1. Her iki ülkenin yüksek katma değer sağlayacak faaliyet alanlarını belirlediği ve bu alanlara yönelik Ar-Ge faaliyetlerinin desteklenmesini ve teşvik edilmesini ön plana çıararak bu alanlarda faaliyet gösteren teknoloji yoğun yüksek katma değerli sektörleri öncelikledikleri,

2. Her iki ülkenin optimal sayıda ve sürede teşvik uygulamalarını hayata geçirerek bu teşvikleri belli kurallar ile yaptırımlar çerçevesinde takip ettikleri,

Türkiye'nin uyguladığı teşvik politikasına baktığımızda başarılı teşvik politikaları uygulayan ülkelerden farklı olarak iki nokta gözümüze çarpmaktadır. Bunlardan ilki Türkiye’nin hemen hemen her alanda bir teşvik programına sahip olması ve bu kadar çok sayıda olan teşvik programının veriminin analiz edilememesi ve takibinin yapılamamasıdır. Ayrıca, verimliliği esas almadan uygulanan teşvikler ile sağlanan kazanımlar açık ve ölçülebilir olmadığından dolayı teşviklerin etkinliği de net bir şekilde ortaya konulamamaktadır (Takım ve Ersungur, 2018). Örneğin verilen teşviklerin araştırma geliştirme faaliyetlerini, ihracatı, ekonomik büyümeyi ve diğer makroekonomik değişkenleri ne oranda etkilediği net olarak bilinmemektedir.

İhracat temelli büyümeyi kendisine hedef edinen Türkiye’nin son on yllda orta gelir tuzağından çıkamamasının ve ihracatında kayda değer bir ilerleme yaşanmamasının, Türkiye’nin yapmış olduğu ihracatın $\mathrm{Kg}$ değerinin diğer ülkelere kıyasla oldukça düşük olmasından kaynakladığı görülmektedir. Diğer bir ifadeyle Türkiye’nin ihracatı içerisindeki katma değeri yüksek, teknoloji yoğun ürünlerin oranının oldukça düşük olduğu söylenebilir. Bu doğrultuda, Türkiye’nin mevcut teşvik sistemini, verimliliği esas alan, yüksek katma değer sağlayacak faaliyet alanlarını belirleyerek bu alanlara yönelik Ar-Ge faaliyetlerini destekleyen ve bu alanda faaliyet gösteren sektörleri öncelikleyen bir teşvik sistemine dönüştürmesi gerekmektedir.

Türkiye'de imalat sanayinin alt sektörlerinin davranış biçimlerinin, yapılarının ve ihtiyaçlarının birbirlerinden farklılık gösterdiği sonucunun ortaya konduğu bu çalışma devlet desteklerinin 
de söz konusu sektörlerin yapıları ve ihtiyaçları göz önünde bulundurularak programlanması gerektiği sonucunu ortaya koymaktadır.

\section{Kaynakça}

Açıkel, Z.,(2018). Turquality Projesi Kapsamındaki Mobilya Sektörü İşletmelerinin Uluslararası Pazarlardaki Tutundurma Faaliyetlerinin İncelenmesi. Yönetim, Ekonomi ve Pazarlama Araştırmaları Dergisi, 2(1): 14-28.

Akdeve, K., ve Karagöl, E., T., (2013) Geçmişten Günümüze Türkiye’de Teşvikler Ve Ülke Uygulamaları, Dumlupinar Üniversitesi Sosyal Bilimler Dergisi.

Ankara Ticaret Odası, (2000). Türkiye'de Uygulanan Teşvik Politikaları, www.zucder.org.tr/zucder/docs/ tesvik_politikalari.doc, Erişim tarihi: 19.08.2020

Chine Ministry of Science and Technology,(2007).S\&T Programmes. http://www.most.gov.cn/eng/ programmes, Erişim tarihi: 11.08.2020.

Cho, K., Kim C. ve Shin J., (2015). Differentialeffects of intellectual property rights on innovation and economic performance: A cross-industry investigation. Science and Public Policy, Oxford University Press, 42(6): 827-840.

Cohen, W.M., Nelson, R.R. ve Walsh, J. (1997). Appropnability conditions and why firms patent and why they do not in the U.S. manufacturing sector, Carnegie Mellon University Working Paper, 1998, Pittsburgh, PA

Çaklı, S., (1998).İktisat Politikası Düşüncesinin Evrimi. Ankara:Gazi Kitabevi.

Çiloğlu, İ., (1997). Teşvik Sisteminin Değerlendirilmesi. Hazine Dergisi, 8:1-15.

Devlet Planlama Teşkilatı, (1982). Beşinci Beş Yıllık Kalkınma Planı Yatırımların ve İhracatın Teşviki Özel İhtisas Komisyonu Raporu, DPT Yayınları, Ankara.

Devlet Planlama Teşkilatı, (1989). Altıncı Beş Yıllık Kalkınma Planı Yatırımları Teşviki Özel İhtisas Komisyonu Raporu, DPT Yayınları, Ankara.

Devlet Planlama Teşkilatı, (2000). Sekizinci Beş Yıllık Kalkınma Planı Rekabet Hukuku ve Politikaları Özel İhtisas Komisyonu Raporu, DPT Yayınları, Ankara.

Devlet Planlama Teşkilatı, (2003).Devlet Yardımlarını Değerlendirme Özel İhtisas Komisyonu Raporu, DPT Yayınları, Ankara.

Devlet Planlama Teşkilatı, (2007). Dokuzuncu Kalkınma Plan ^ Devlet Yardımları Özel İhtisas Komisyonu Raporu, DPT Yayınları, Ankara.

Duran, M., (1998). Türkiyede Uygulanan Yatırım Teşvik Politikaları (1968-1998), Başbakanlık Hazine Müsteşarlığı Ekonomik Araştırmalar Genel Müdürlüğü, Araştırma ve İnceleme Dizisi, No:19, Ankara.

Eser, E.,(2011). Türkiye’de Uygulanan Yatırım Teşvik Sistemleri ve Mevcut Sistemin yapısına Yönelik Öneriler, DPT Uzmanlık Tezi.

Fink, C. Ve Maskus, K. (2005).Intellectual Property and Development, World Bank. Industry-Level Analysis Report, Intellectual Property Rights Intensive Industries: Contribution to economic performance and employment in the EU, EPO ve OHIM Ortak Projesi.

Gould, D. M. ve Gruben, W. C. (1996).The role of intellectual property rights in economic growth. Journal of Development Economics, 48: 323-50. 
Günem, O., E., (2007). Gelişmekte Olan Ülkelerde Doğrudan Yabancı Yatırımlara Yönelik Teşviklerin Etkileri: 1980 Sonrası Türkiye Örneği, Marmara Üniversitesi Sosyal Bilimler Enstitüsü, Yüksek Lisans Tezi, İstanbul.

Hassan, A., Yaqub, O., İepeveen, S., (2010). Intellectual Property and Developing Countries.

İspanya Patent ve Marka Ofisi, (2003). Concordance with Classification of Locarno and NACE, İspanya.

Karakurt, A., (2010). Küresel Kriz Ortamında yatırım Teşvikleri. Ankara Üniversitesi SBF Dergisi: 65(2): 153.

Kazgan, G.,(1978). İktisadi Düşünce, İstanbul: Remzi Kitabevi.

Kızartıcı, H., (2006). İhracata Yönelik Devlet Yardımları, www.tobb.org.tr/abm /haberler/abdisbirligi/ Hakan\%20Kızartıcı\%20SunusTOBB-24.07.2006.ppt, Erişim tarihi: 20.11.2020

Kim, Y. K., Lee, K., Park, W. G. ve Choo, K. N. (2012).Appropriate intellectual property protection and economic growth in countries at different levels of development. ResearchPolicy, 41: 358-75.

Kotler, P.,Wong, V., Saunders, J. ve Armstrong, G. (2004). Principles of Marketing Fourth European Edition. London: Financial Times-Prentice Hall.

Küçükoğlu, M. (2005). Vergisel Teşviklerin Bölgesel Kalkınmadaki Rolü: Güneydoğu Anadolu Bölgesi Üzerine Uygulama. Yayınlanmamış Doktora Tezi, Uludağ Üniversitesi, Sosyal Bilimler Enstitüsü, Maliye Anabilim Dalı, Bursa.

Lall, S. (2003). Indicators of the relative importance of IPRs in developing countries. ResearchPolicy, 32: 1657-80.

Lu, D.,(1999). Industrial policy and resource allocation: implications on China's participation in globalisation. China Economic Review, 11.

Mansfield, E., (1986).Patents and innovation: An empirical study, Management Science, 32: 173-181.

Maskus, K.E. ve Konan, D.E. (1994). Trade-Related Intellectual Property Rights: Issue and Exploratory Results, University of Michigan Press: 401-54.

Maskus, K.E. andPenubarti, M. (1995). How Trade-related Are Intellectual Property Rights? ,Journal of International Economics 39(3-4): 227-248.

Ministry of Finance and Economy Republic of Korea and KDI School of Public Policy and Management, (2006). A Way Forward for the Turkish Economy: Lessons from Korean Experiences, Knowledge Sharing Project.

O’Donnell, R.,(1998). Ireland's Economic Transformation: Industrial Policy, European Integration and Social Partnership, University of Pittsburgh Center for West European Studies and the European Union Center Working Paper, No.2, Pittsburg.

OECD (2008). The Internationalisation of Business R\&D: Evidence, Impacts and Implications, Paris.

Oshima, H.,(1993). Strategic processes in monsoon Asia's economic development, The John Hopkins UniversityPress.

Özbaysal, T.,ve Onay, M., (2017). Markalaşmanın Uluslararasılaşmaya Etkisi: Turquality Örneği, 2017.

Özcan, M., (2008). İrlanda Ekonomisi ve Küresel Ekonomik Kriz, Uluslararası Ekonomik Sorunlar Dergisi.

Park, W. G. veGinarte, J. (1997).Intellectual property rights and economic growth, Contemporary Economic Policy, 15: 51-61.

Ruane, F., (2003). Foreign Direct Investment in Ireland, LancasterUniversity Management School Working Paper,No.2003/005.

Sarı̈z, Y. (2006). Türkiye’de 1990 Sonrası Uygulanan Yatırım Teşvikleri ve Ekonomik Etkileri, Yayınlanmamış Yüksek Lisans Tezi, Gazi Üniversitesi, Sosyal Bilimler Enstitüsü, İktisat Anabilim Dalı, Ankara. 
Schmoch, U., Laville, F., Patel, P., Frietsch, R., (2003). Linking Technology Areas to Industrial Sectors. Final Report to the European Commission, DG Research, Karlsruhe: Fraunhofer ISI.

Sigurdson, J., (2003).Kina - Denn yastormakteninomteknologiochvetenskap, SvenskaDagbladet, Stockholm.

Smith, P.J. (2001). How Do Foreign Patent Rights Affect US Exports, Affiliate Sales and Licenses?,Journal of International Economics 55(2): 411-439.

Şener, H.,Y., ve Bişğin, M., (2014). Turqualıty Programının Markalara Sağladığı Katma Değer: Sarar Markası İçin Vaka Analizi, Pazarlama ve Pazar Araştırmaları Dergisi, 01(01).

Şenses, F., (2009).Neoliberal Küreselleşme ve Kalkınma: Seçme yazılar, İletişim yayınları, İstanbul.

Takım, A .,ve Ersungur, Ş , (2018). Türkiye’de Teşvik Sisteminin Yapısı, Sorunları Ve Etkinliği Üzerine Bir Politika Önerisi: Tek Bir Uygulamacı Kuruluş Sorunları Çözer mi?,Atatürk Üniversitesi İktisadi ve İdari Bilimler Dergisi, 32(3): 725-744.

Thompson, M. A. ve Rushing, F. W. (1996) . An empirical analysis of the impact of patent protection on economic growth, Journal of Economic Development, 21:61-79.

Tosun, E.,(1996). Türkiye’de Kamu Kesimi Özel Kesim Ayrımının Normatif ve Reel Planda Önemi ve Sın ırları, Devlet Bütçe Uzmanlığı Araştırma Raporu, Ankara.

Varsakelis, N. (2001).The impact of patent protection, openness, and national culture on R\&D investment: A cross-country empirical investigation, Research Policy, 30: 1059-68.

Yerebakan, M. (2007). Türkiye İçin Model Olabilecek Ülkelerde Uygulanan Teşvik Uygulamaları Ve Ülkemize Uygulanabilirliği, İstanbul Ticaret Odası Yayınları, Yayın No:2007-51, İstanbul.http:// www.yoikk.gov.tr/detay.cfm?MID=1, Erişim tarihi: 19.07.2020

Yusuf, S. ve Kaoru N.,(2007). Strengthening China’s Technological Capability ,Policy Research Working Paper No.4309.

www.agtm.sanayi.gov.tr/Agm/ArgeDetay, Erişim tarihi: 10.06.2020

www.btgm.sanayi.gov.tr/Handlers/DokumanGetHandler.ashx?dokumanId=3cc49230-9bb0-4a6f-bbedc73edd20459, Erişim tarihi: 14.05.2020

www.sanayi.gov.tr/istatistikler/istatistiki-bilgiler/mi020.301.1502, Erişim tarihi: 10.05.2019

www.tim.org.tr/tr/ihracat-rakamlari, Erişim tarihi: 10.02.2020

www.turquality.com/, Erişim tarihi: 10.05.2020

www.turquality.com/hakkimizda, Erişim tarihi: 19.07.2019

www.turquality.com/hakkimizda/misyon-ve-hedeflerimiz, Erişim tarihi: 19.07.2019

www.turquality.com/markalar/turquality-destek-programi-kapsamindaki-firmalar, Erişim tarihi: 19.07.2019

www.turkpatent.gov.tr/TURKPATENT/statistics/, Erişim tarihi: 13.01.2019 